NBER WORKING PAPER SERIES

\title{
MARRYING YOUR MOM: PREFERENCE \\ TRANSMISSION AND WOMEN'S \\ LABOR AND EDUCATION CHOICES
}

\author{
Raquel Fernández \\ Alessandra Fogli \\ Claudia Olivetti
}

Working Paper 9234

http://www.nber.org/papers/w9234

\author{
NATIONAL BUREAU OF ECONOMIC RESEARCH \\ 1050 Massachusetts Avenue \\ Cambridge, MA 02138 \\ October 2002
}

We thank Daron Acemoglu, Mark Gertler, Per Krusell, Kevin Lang, Fabrizio Perri, Torsten Persson, and Jonathan Portes for helpful comments. We also thank seminar participants at BU, ESSIM, IIES, Indiana U., MIT, NBER, Northwestern U., NYU, SED, Stanford U., Stockholm School of Economics, UC Davis, UCLA, and U. of Madison-Wisconsin. The first author thanks the CV Starr Center and the NSF for financial support. The views expressed herein are those of the authors and not necessarily those of the National Bureau of Economic Research.

(C) 2002 by Raquel Fernández, Alessandra Fogli, and Claudia Olivetti. All rights reserved. Short sections of text, not to exceed two paragraphs, may be quoted without explicit permission provided that full credit, including $(\mathcal{C}$ notice, is given to the source. 
Marrying Your Mom: Preference Transmission and Women's Labor and Education Choices Raquel Fernández Alessandra Fogli, and Claudia Olivetti

NBER Working Paper No. 9234

October 2002

JEL No. J12, I20, Z10, D19

\begin{abstract}
This paper argues that the evolution of male preferences contributed to the dramatic increase in the proportion of working and educated women in the population over time. Male preferences evolved because some men experienced a different family model—one in which their mother was skilled and/or worked. These men, we hypothesize, were more inclined to marry women who themselves were skilled or worked. Our model endogenizes the evolution of preferences in a dynamic setting and examines how it affected women's education and labor choices. We present empirical evidence based on GSS data that favors our transmission mechanism. We show that men whose mothers were more educated or worked are more likely to marry similar women themselves.
\end{abstract}

Raquel Fernández

Department of Economics

New York University

269 Mercer Street

New York, NY 10003

and NBER

raquel.fernandez@nyu.edu

Claudia Olivetti

Boston University

Boston, MA 02215
Alessandra Fogli

Department of Economics

New York University

269 Mercer Street

New York, NY 10003 


\section{Introduction}

Women's role in the US economy has dramatically changed during the last century: whereas at the beginning of the century women tended to have low labor force participation rates, be less educated than men, and to exit the formal labor market upon marriage, today almost $50 \%$ of the labor force is female, more women than men complete college, and women make up some $36 \%$ of professionals. ${ }^{1}$ These changes have been accompanied by an equally radical shift in attitudes towards woman's role in the economy and the family. A Gallup poll conducted in 1938, for example, asked "Do you approve or disapprove of a married woman earning money in business or industry if she has a husband capable of supporting her?" A resounding $81 \%$ of men responded negatively. ${ }^{2}$ The same question posed by the General Social Survey (GSS) showed that this fraction had declined to 38\% of the white male population by $1972,25 \%$ in 1982, and $17 \%$ in 1998 .

What are the factors responsible for this profound transformation in the role that women play in the family and in the workplace? The explanations that have been proposed range from the liberating effects of new consumer durables that, as suggested by Greenwood, Seshadri and Yorukoglu (2001), greatly decreased the amount of work required to run a household (e.g., washing machine, vacuum cleaner, etc.), to the revolutionary effect of the oral contraceptive (the pill) that, as argued by Goldin and Katz (2000), facilitated a woman's investment in her career by almost eliminating the chance of an accidental pregnancy. It has also been argued that the expansion of the service sector, with its attendant white collar jobs and/or skilled-biased technological change, greatly facilitated this transformation (see Goldin (1990) for this argument and Galor and Weil (1996) for a model that relates skill-biased technological change to fertility and labor choices).

Is there, however, a causal relationship between the change in male attitudes and the changed role of women? Our paper suggests that the evolution of male attitudes may have played an important role in bringing about the transformation in female education and work decisions. We argue that over time there was an evolution in male attitudes towards educated and working women brought about by some men experiencing a different family model-one in which their mother was skilled and/or worked. This experience, we suggest, changed male preferences and increased the probability of skilled women marrying by making these men either more attractive as spouses for skilled/working women or more interested

\footnotetext{
${ }^{1}$ US Census Bureau, Current Population Survey, and Goldin and Katz (2000).

${ }^{2}$ Erskine (1971).
} 
themselves in marrying them (or both). The more favorable attitudes of these men, in turn, affected the relative attractiveness of becoming a skilled working woman as compared to a woman whose work was primarily in the household. Over time, this led to more households formed by skilled women, a greater proportion of men with these alternative preferences, and an increase in the relative supply of skilled/working women. Thus, the gradual transformation of the family-long considered a source of transmission of moral, religious and cultural beliefs-itself acted as a reinforcing mechanism of changes in women's role. In this way, women who worked (or obtained a higher level of education) set an example for their sons, and thus made it easier for the next generation of women to follow in their footsteps. ${ }^{3}$

We develop a model in which women first choose to become skilled or unskilled, and then get married and have children or remain single. The relative attractiveness of becoming skilled depends on relative wages, on the probability of finding a good match, and on the idiosyncratic (utility) cost that a woman must bear to become skilled. In our model, the probability of finding a good match is endogenous and depends on the proportion of men who have skilled mothers. We examine the dynamic evolution of the economy and show that over time the fraction of skilled women who marry increases relative to that of less skilled women, thus increasing the proportion of men born to skilled women.

The mechanism that we single out for attention is the transmission of different preferences in the family that changed the probability of marriage of skilled relative to unskilled women and thus the attractiveness of being skilled and/or working for women. This is undoubtedly not the entire story and other factors such as technological change, the rise of the clerical and service sector, or the introduction of oral contraception undoubtedly played important roles over different periods of time. Nonetheless, it is interesting to note that historically the probability of a woman with a college degree or above remaining single was a bit over $31 \%$ for the cohort born in 1890 and graduating college around 1910 as compared to $7.8 \%$ for her non-college counterparts. The same statistic for college-graduate men of that

\footnotetext{
${ }^{3}$ Of course, as more women joined the labor force and attended college, attitudes towards these women changed in society at large. Our argument does not preclude this additional transmission mechanism. We emphasize, both theoretically and empirically, however, the role played directly by having a mother of a different type. There is additional evidence that favors parental roles as a transmission mechanism. Thornton et. al. (1983), for example, find that parental gender-role attitudes and parental education affect their children's genderrole attitutides. Wilkie (1988) finds a similar effect of mother's labor force participation on children's gender-role attitudes.
} 
generation was around $10.2 \%$ compared to an $11.4 \%$ for non-college graduates. As we show in Figure 1, there has been a dramatic decline over time in the ratio of the probability of remaining single for skilled (college and above) relative to less skilled (less than college graduates) women. ${ }^{4}$ For the generation born in 1950 (attending college around 1970), only $7.9 \%$ of college-graduate women remained single as compared to around $5.5 \%$ of her non-college counterparts. This behavior was more similar to that of men, for whom $7.5 \%$ of college graduates remained single as compared to $8.2 \%$ of non-college graduates. ${ }^{5}$ It is interesting to note, as also shown in Figure 1, that it is only recently that the relative marriage probabilities of skilled and unskilled individuals is similar for men and women.

Our empirical analysis provides evidence that supports our basic transmission mechanism-the hypothesis that men tend to marry women who are similar to their mothers. ${ }^{6}$ Using GSS data, we show that the probability of a man's wife working is positively and significantly correlated with whether his mother worked. Even after controlling for factors such as the man's age, income, education, and number of children, his wife's age and education, and various other family background variables including location, we find that having a mother who works increases the probability of a wife working by 32 percentage points. ${ }^{7}$ Using similar controls, we also find that the education of a man's mother, unlike that of his father, has a positive and significant impact on the years of education possessed by the woman he marries.

In addition to the aforementioned papers that attempt to explain why women's education and labor force decisions have changed, our paper is related to several other literatures. There is a large empirical and historical literature on women's labor force participation (see Killingsworth and Heckman (1986) and Altonji and Blank (1999) for surveys). Goldin (1990) provides an extensive account of the change in women's role in the work place and its consequences for the evolution

\footnotetext{
${ }^{4}$ The general pattern is the same independent of the definition of skilled (more educated) versus unskilled (less educated) that one uses.

${ }^{5}$ The figures above are for the probability of marriage before the age of 45 . The statistics for women are from Goldin (1997) and from CPS March Supplemental File. The statistics for men are calculated by the authors from CPS March Supplemental File (several years).

${ }^{6}$ Since the work of Freud, psychoanalytic theory has claimed that individuals tend to choose spouses that are similar to opposite-sex parents. Some studies (e.g., Wilson and Barrett (1987) Geher (2000) ) find empirical evidence that individuals tend to choose spouses who have similar physical characteristics and personality traits to their opposite-sex parents.

${ }^{7}$ Del Boca, Locatelli and Pasqua (2000) using data from the 1995 Bank of Italy Survey, also reports a strong positive and significant effect of mothers' working experience on the probability that their sons' wives work.
} 
of gender differences in pay since the beginning of the twentieth century. More closely related is Goldin (1997) which provides an illuminating account of how work, marriage and family options have changed over time by studying four generations of women. Pencavel (1998) examines the more recent history from 1975-94 and concludes that increases in own wages account for between one quarter to a half of the increase in women's labor supply (depending on the generation), with the increased attractiveness of the marketplace relative to the household accounting for the rest. ${ }^{8}$ Costa (2000) examines the evolution of women's paid labor for several countries and Blau and Kahn (2000) examine the evolution of gender differences in pay.

Our paper is also related to a recent literature that examines how preferences are transmitted within the family. Bisin and Verdier (2000) examine the interaction of the marriage market with the endogenous transmission of cultural preferences. Galor and Moav (2002) argue that the (genetic) transmission of preferences favoring quality over quantity of children helps understand the history of economic growth. Lastly, our paper belongs to a growing literature that is interested in the effects of how (and why) individuals sort in particular ways in marriage, intrafamily interactions, and the consequences of this for the macroeconomy. Fogli (2000) studies the effects of different family arrangements on labor market outcomes. Kremer (1997) and Fernández and Rogerson (2001) examine the consequences of marital sorting for inequality whereas Fernández, Guner and Knowles (2001) use cross-country household data to examine the relationship between sorting, inequality and growth.

This paper is organized as follows. In the next section we develop a simple dynamic model that endogenizes the diffusion of preferences and traces out the dynamic evolution of the economy. In the third section we present evidence that supports the idea that a man marries a woman similar to his mother. In the fourth section we conclude.

\section{The Model}

The objective of this section is to develop a dynamic model that analyzes women's education and labor force participation decisions as a function of the endogenously

\footnotetext{
${ }^{8}$ Olivetti (2001) quantifies the relative effect of the increase in the returns to labor market experience and of the decline in the gender wage gap on married women's life cycle labor supply. Jones, Manuelli and McGrattan (2001) study the effects of the gender wage gap and divorce on married women's labor force participation.
} 
evolving preferences within the male population. The predictions of this model should be consistent with the fact that over time women's labor force participation has increased, women have become more educated, marriage patterns for skilled women have become similar to that of unskilled women, and male attitudes towards married working women have become more favorable.

We make a few assumptions that render the model considerably more tractable. While we assume women can choose to become either skilled $s$ or unskilled $u$, men are assumed to have a homogeneous skill level. Men instead differ in the type of mother they have ( $s$ versus $u$ ). Their mother matters, as we shall see shortly, as skilled women are assumed to transmit different preferences to their sons than unskilled women. ${ }^{9}$ Thus, instead of having four types of men and women, we have two types for each sex, skilled $(s)$ and unskilled $(u)$, where type indexes education for women and their mother's education for men.

The timing in the model is as follows. First, given the distribution of men (which is equivalent to that of their mothers'), women decide whether to become skilled or unskilled. Agents then obtain a match in the marriage market with a constant probability. Given this match, they decide whether to marry or to stay single. Lastly, married agents have $n$ children (on aggregate, half female, half male), and decide how to allocate their time between work and the household. Single agents remain childless. Hence, the education and marital distribution of women in the previous period's generation determine the distribution of male types for this period's generation. This, in turn, will determine the indirect return to women of becoming skilled relative to unskilled in this generation.

\subsection{Household Decisions}

As shown in Figure 1, in the past skilled women married at a significantly lower rate than unskilled women-a feature of the marriage market that over time has slowly disappeared. One possible explanation for this disparity is that skilled women, for a variety of reasons, were deemed to be less attractive marital partners than unskilled women. Another possibility is that skilled women were pickier both than their male counterpart and than unskilled women. In this model we tie together the fact that in the past men overwhelmingly disapproved of married women working with the lower marriage probability faced by skilled women. As

\footnotetext{
${ }^{9}$ The preferences of daughters, on the other hand, are independent of their mothers. This is of course a simplifying assumption as one important role that skilled women play is undoubtedly transmitting different preferences (gender roles) to their daughters.
} 
is shown below, the marriage "penalty" emerges endogenously as a consequence of skilled women's higher wages and the time allocation decisions that these generate.

The welfare of individual $i$ who is married to another agent $j$, consists of utility from own private consumption $c_{i}$, some spillover $\alpha_{i}$ from the spouse's consumption $c_{j}$, utility from consumption of a household public good $c$, and utility from the quality of the match with $j$ as perceived by agent $i, q_{i j} .{ }^{10}$ Match quality $q \in$ $[-\infty, \infty]$ is assumed to be a random draw from a distribution $Q$. Each agent is endowed with a unit of time which can be allocated between producing the household public good and working in the market. We assume that given a total time investment of $T=t_{i}+t_{j}$, each agent obtains $c=T n$ units of the public good. ${ }^{11}$ Each agent's private consumption is equal to her earnings, which is the product of the time the agent spends working and her wages, i.e., $c_{k}=\left(1-t_{k}\right) w_{k}$, $k=i, j$.

Agent $i$ 's utility when married to agent $j, V_{i}^{j}$, is given by:

$$
V_{i}^{j}\left(w_{i}, w_{j}, q_{i}\right)=\max _{0 \leq t_{i} \leq 1}\left[\left(1-t_{i}\right) w_{i}+\alpha_{i}\left(1-t_{j}\right) w_{j}+\beta \log \left(t_{i}+t_{j}\right) n+q_{i j}\right]
$$

where $i$ takes $t_{j}$ as given and $\beta>0,0 \leq \alpha_{i}<1$.

The first order condition yields:

$$
\begin{gathered}
-w_{i}+\frac{\beta}{t_{i}+t_{j}}+\eta_{i}+\mu_{i}=0 \\
\eta_{i} \geq 0 \quad \eta_{i} t_{i}=0 \quad \mu_{i} \geq 0 \quad \mu_{i}\left(1-t_{i}\right)=0
\end{gathered}
$$

Note that equation (2.2) implies that if $w_{i} \neq w_{j}$, then at least one of the agents must be at a corner solution. We assume throughout $w_{m}>w_{f}$, where $m$ is male and $f=s, u$ indexes female wages according to whether the woman is skilled or not and $w_{s}>w_{u}$. There are three possible cases: (i) $w_{m}>\beta>w_{f}$, then $t_{m}=0$ and $t_{f}=1$; (ii) $w_{m}>w_{f}>\beta$, then $t_{m}=0$ and $t_{f}=\beta / w_{f}$; (iii) $\beta>w_{m}>w_{f}$, $t_{m}=t_{f}=1$. In the last case, both spouses devote themselves full time to the production of the household public good, so we will ignore this possibility

\footnotetext{
${ }^{10}$ One possible interpretation of the utility function is that individuals obtain utility from their career in a way that is proportional to its status or success as measured by wages. In such an interpretation, $\alpha_{i}$ is the utility agent $i$ derives from her/his spouse's career.

${ }^{11}$ One interpretation of this good is children, where $n$ is the number of children, and the total time $T$ invested in them determines their quality.
} 
and restrict our attention to the first two. Note that in the first case, the wife does not work and instead dedicates herself full time to the raising of children while the husband works full time. In the second case, the husband's situation is unchanged, but the wife works part time and raises children with the remainder of her time.

We next characterize the utility of a married man, $V_{m}$, as a function of his wife's wage $w_{f}$ (maintaining throughout the assumption of $w_{m}>w_{f}$ ). Note first that for $w_{f} \in[0, \beta)$, the wife does not change her time allocation in response to changes in $w_{f}$ (she is devoted full-time to household production), and hence there is no effect on the husband's utility. For $w_{f} \in\left[\beta, \beta / \alpha_{m}\right]$, the husband's utility is decreasing as a function of $w_{f}$; in this interval an increase in $w_{f}$ leads the wife to decrease the amount of time spent at home thereby decreasing the man's utility by $\left(\beta-\alpha_{m} w_{f}\right) d w_{f} / w f$. For $w_{f}>\beta / \alpha_{m}$, the husband's utility is strictly increasing in $w_{f}$ despite the fact that the wife is putting in less time at home. Figure 2.1 depicts a married man's utility as a function of his wife's wage for two different values of $\alpha_{m}$.

\subsection{Preference Transmission}

We assume that a skilled mother transmits preferences such that her son has a stronger preference for skilled women than a man born to an unskilled mother. There are several ways of modelling this. One possibility is to assume that men with skilled mothers inherit a higher value of $\alpha_{m}$ and thus obtain greater utility from their wife's consumption or, in the career interpretation alluded to in footnote 9 , obtain greater utility from their wife's career. Thus, men with skilled mothers have $\alpha_{m s}>\alpha_{m u}$ (where $i$ indexes the mother's type, $s$ or $u$ ) and therefore, as shown in Figure 2.1, for any given wage, obtain higher utility from a match in which a woman would choose to work.

Alternatively, we could have modelled all consumption as joint and thus have both spouses in agreement on the optimality of each other's work decision, but

simply have assumed that men preferred women who are like their mothers in that, for the same random draw $q$ of match quality, they obtain higher utility if the woman is the same skill type as their mother, i.e.,

$$
q_{i j}= \begin{cases}A_{h} q & \text { for } i=j \\ A_{l} q & \text { for } i \neq j\end{cases}
$$

where $A_{h}>A_{l}>0$ and $i$ is a male. The first modelling route has the advantage, 
however, that it also provides an explanation of why men disapproved of women working-for a range of wages, it implies that women will make work decisions that make men worse off.

Henceforth we assume that (female) unskilled wages $w_{u}$ lie in the interval $[0, \beta)$ (i.e., an unskilled woman is a housewife) and skilled wages $w_{s}$ lie in the interval $\left[\beta, \widehat{w}_{f}\left(\alpha_{m u}\right)\right)$ (i.e., skilled women work in the market as well as at home) where $\widehat{w}_{f}\left(\alpha_{m i}\right)$ solves:

$$
\alpha_{m i} w_{f}+\beta \log \frac{\beta}{w_{f}}=0
$$

guaranteeing that, for the same $q_{i j}$, men with skilled mothers prefer skilled women and men with unskilled mothers prefer unskilled women. See Figure 2.1 for a depiction of these various intervals.

Note that the fact that men born to skilled mothers like skilled women more than men born to unskilled women does not depend on the wage range chosen. Our choice of wage range for skilled relative to unskilled women, however, guarantees that men born to skilled women strictly prefer skilled over unskilled women and viceversa for men born to unskilled women. This is a sufficient, but not necessary, condition to match the fact that skilled women had a lower marriage probability than unskilled women when the proportion of men born to skilled women is low. ${ }^{12}$ To summarize, we have:

$$
\widehat{w}_{f}\left(\alpha_{m u}\right)>w_{s}>\widehat{w_{f}}\left(\alpha_{m s}\right)>\beta>w_{u}
$$

Note that we have assumed that spouses are unable to compensate one another and, in particular, that the higher-paid husband cannot "bribe" his wife to put in more time at home by transferring income to her. This is not a necessary component of our model, however. ${ }^{13}$ If a man could bribe his wife to stay at home, he would still prefer an unskilled wife to a skilled one for a large range of wages. For $w_{f} \in\left(\beta, \beta / \alpha_{m i}\right)$ every additional increment to time spent working in the market makes the husband worse off-hence he will prefer an unskilled wife to a skilled one. For wages higher than $\beta / \alpha_{m i}$, the husband would bribe the wife to spend less time at work but still have her participate some time in the market since the marginal value of the last unit of time spent at home full-time is $\beta$ which is less than $\alpha_{m i} w_{f}$. Hence there will exist some wage greater than $\beta / \alpha_{m i}$ such

\footnotetext{
${ }^{12}$ It is not a necessary condition given that skilled women are pickier than unskilled women since, as will be seen later, they have better outside options.

${ }^{13}$ See Lundberg and Pollak (2001) for an example of location decisions driving inefficient outcomes in the household.
} 
that for higher wages a man prefers a skilled wife. Note that this wage would be lower for a man born to a skilled mother than to an unskilled mother.

\subsection{Marriage Decision}

We next turn to the matching part of our model. The simplest way to model this is as a one-period random search in which the probability of a given individual meeting another individual (of a different sex) of type $j$ is given by $\pi_{j}$, where $\pi_{j}$ is the proportion of type $j$ in that respective gender's population. Matched individuals each obtain a random draw of match quality $q \in[-\infty, \infty]$ from a distribution $Q$. Individuals then decide whether to stay in a match (marry) and obtain married utility $V_{i}^{j}$ as in equation (2.1) or to remain single whereby her/his utility is given by:

$$
U\left(w_{i}\right)=w_{i}
$$

that is, there is no household public good nor any externality from another agent's consumption. iff:

Hence agent $i$ will be willing to marry agent $j$ iff $V_{i}^{j}\left(w_{i}, w_{j}, q_{i j}\right) \geq U_{i}\left(w_{i}\right)$, i.e.,

$$
\alpha_{i}\left(1-t_{j}\right) w_{j}-w_{i} t_{i}+\beta \log \left(t_{i}+t_{j}\right) n+q_{i j} \geq 0
$$

where $i \in(s, u)$ indexes the skill type of the man's mother if $i$ is a male or the skill type of the woman if $i$ is female, and similarly for $j$. Thus, we can solve for the reservation qualities, $q^{*}$, of males and females according to their type. This yields:

$$
\begin{gathered}
q_{m i j}^{*}=\left\{\begin{array}{c}
-\beta \log n \quad \text { if } j=u \\
\alpha_{m i}\left(\beta-w_{s}\right)-\beta \log \frac{\beta}{w_{s}} n \text { if } j=s
\end{array}\right. \\
q_{f i}^{*}=\left\{\begin{array}{c}
w_{u}-\alpha_{f} w_{m}-\beta \log n \quad \text { if } i=u \\
\left(\beta-\alpha_{f} w_{m}\right)-\beta \log \frac{\beta}{w_{s}} n \text { if } i=s
\end{array}\right.
\end{gathered}
$$

for $i, j=s, u$.

The first line of $q_{f i}^{*}$ is the reservation quality of unskilled females, whereas the second is that of skilled females. Note that male pickiness is invariant to his own wage (since he works full time whether married or single) and invariant to female wages if these are below $\beta$. For female wages above $\beta$, as discussed previously, the effect of an increase in female wages on men's reservation quality is given by the sign of $-\alpha_{m i}+\frac{\beta}{w_{f}}$. Female pickiness, on the other hand, is always increasing 
in her own wage and decreasing in men's wages. Note that (2.5) implies that $q_{m u s}^{*}>q_{m i u}^{*}>q_{m s s}^{*}{ }^{14}$

An immediate implication of the search model is that the greater is the fraction of men with skilled mothers $\left(\lambda_{m}\right)$, ceteris paribus, the larger is the proportion of skilled women that end up married (since they are rejected a lower percentage of times) whereas the proportion of unskilled women that end up married stays constant (since both types of men have the same reservation utilities for unskilled women). Note that in our simple formulation, the utility of a married woman is independent of the type of man she marries. Nonetheless, the expected utility of a skilled woman is increasing in $\lambda_{m}$ since it decreases the probability of being rejected when she wants to marry.

\subsection{Education Decision}

We next turn to the female education decision. We assume that a woman faces an idiosyncratic (utility) cost of becoming skilled of $\gamma$ where the latter is an iid random draw from a continuous cumulative distribution function $G(\gamma)$ with support $[0, \infty]$. Note that the probability of a woman meeting a type $j$ man, $\pi_{j}$, equals $\lambda_{m}$ if $j=s$ and $1-\lambda_{m}$ if $j=u$.

Let $p_{i j}$ be the probability faced by a woman of type $i$ of marrying a man of type $j$, i.e.,

$$
p_{i j}\left(\lambda_{m}\right)=\pi_{j} \int_{q_{m j i}^{*}}^{\infty} \int_{q_{f i}^{*}}^{\infty} d Q(q) d Q(q)
$$

Note that $p_{i j}$ is only a function of $\lambda_{m}$. Thus, the expected utility $V^{i}$ of a woman of type $i=s, u$ given that the fraction of men born to skilled women is $\lambda_{m}$, is given by:

$$
V^{i}\left(\lambda_{m}\right)=\sum_{j=s, u} p_{i j}\left(\lambda_{m}\right) V_{i}^{j}+\left(1-\sum_{j=s, u} p_{i j}\left(\lambda_{m}\right)\right) U\left(w_{i}\right)
$$

Lastly, let

$$
\Delta\left(\lambda_{m}\right) \equiv V^{s}\left(\lambda_{m}\right)-V^{u}\left(\lambda_{m}\right)
$$

\footnotetext{
${ }^{14}$ This follows because both male types have the same reservation quality for unskilled females in our simple model. Our results would all go through, however, if in a slightly more complicated model men with skilled mothers had a higher reservation quality for unskilled women than men with unskilled mothers. That is, the fact that the lowest reservation quality is $q_{m s s}^{*}$ does not drive the results.
} 
be the relative utility of a skilled female (relative to an unskilled female) given $\lambda_{m}$. Note that since wages are constant, the expected utility differential between skilled and unskilled women is independent of the proportion of women who decide to become skilled, $\lambda_{f}{ }^{15}$ All women with $\gamma \leq \Delta\left(\lambda_{m}\right)$ will decide to become skilled. The equilibrium $\lambda_{f}\left(\lambda_{m}\right)$ at any point in time is depicted in Figure 2.2 at the intersection of $\Delta\left(\lambda_{m}\right)$ and $\gamma=G^{-1}\left(\lambda_{f}\right)$.

The effect of an increase in $\lambda_{m}$ is to increase the expected utility of skilled relative to unskilled women by increasing the marriage probability of the former. Thus, as shown in Figure 2.2, the effect of this is to increase the proportion of women who choose to become skilled, i.e., $\lambda_{f}^{\prime}\left(\lambda_{m}\right)>0$. Thus, comparing two economies with different proportions of men born to skilled mothers, ceteris paribus, the one with the greater proportion of these men should also have a higher proportion of skilled women.

\subsection{Dynamics}

Let $F_{i}\left(\lambda_{m t}\right)$ be the number of type $i=s, u$ women that marry given that the fraction of skilled men at time $t$ is $\lambda_{m t}$ and that the fraction of skilled women at time $t, \lambda_{f t}$, is the equilibrium response to this fraction of skilled men, i.e., $\lambda_{f t}\left(\lambda_{m t}\right)$. That is,

$$
F_{i}\left(\lambda_{m t}\right)=\pi_{i t} \sum_{j=s, u} p_{i j t} X_{t}
$$

where $X_{t}$ is the number of women at time $t, \pi_{i t}=\lambda_{f t}$ if $i=s$ and equals $1-\lambda_{f t}$ if $i=u$.

The dynamics of the system are given by:

$$
\lambda_{m t+1}\left(\lambda_{m t}\right)=\frac{F_{s}\left(\lambda_{m t}\right)}{F_{s}\left(\lambda_{m t}\right)+F_{u}\left(\lambda_{m t}\right)}
$$

and thus the proportion of skilled men is an increasing function of this period's proportion iff

$$
\frac{1}{F_{s}} \frac{\partial F_{s}}{\partial \lambda_{m}}>\frac{1}{F_{u}} \frac{\partial F_{u}}{\partial \lambda_{m}}
$$

\footnotetext{
${ }^{15}$ In a more general matching framework (e.g., one with more rounds of matching or in a model of directed search), the utility of being a skilled (or unskilled) woman would in general depend on the fraction of women who choose to become skilled as well, as this would influence the search strategies of the males.
} 
i.e. iff an increase in $\lambda_{m t}$ produces a greater percentage increase in the number of skilled women who marry than in the number of unskilled women who marry.

Proposition 1. $\lambda_{m t+1}$ is a continuous increasing function of $\lambda_{m t}$ on $[0,1]$.

Proof. Taking the derivative of (2.13) with respect to $\lambda_{m}$, it follows from $\lambda_{f}^{\prime}\left(\lambda_{m}\right)>0$ and from $\sum_{j=s, u} p_{s j}^{\prime}\left(\lambda_{m}\right)>0$ that $\frac{\partial F_{s}}{\partial \lambda_{m}}>0$ whereas $\sum_{j=s, u} p_{u j}^{\prime}\left(\lambda_{m}\right)=$ 0 implying $\frac{\partial F_{u}}{\partial \lambda_{m}}<0 .{ }^{16}$ Hence (2.15) holds yielding $\lambda_{m t+1}^{\prime}\left(\lambda_{m t}\right)>0$. Continuity follows from the fact that $\lambda_{f}\left(\lambda_{m}\right)$ is a continuous function.

A steady state is a $\lambda_{m}^{*}$ such that

$$
\lambda_{m t+1}\left(\lambda_{m}^{*}\right)=\frac{F_{s}\left(\lambda_{m}^{*}\right)}{F_{s}\left(\lambda_{m}^{*}\right)+F_{u}\left(\lambda_{m}^{*}\right)}=\lambda_{m}^{*}
$$

We assume:

$$
V^{s}(0)-V^{u}(0)>0
$$

i.e., that when the proportion of men with skilled mothers is zero (and hence skilled women face the lowest feasible marriage probability), the expected utility differential between skilled and unskilled women is such that some women will still choose to become skilled, i.e., $\lambda_{f}(0)>0 .{ }^{17}$ The following proposition follows directly.

Proposition 2. There exists a non-zero locally-stable steady state. Starting from $\lambda_{m}=0$ the transition to this steady state is monotonic.

Proof. Note that $\lambda_{m t+1}(0)>0$ and $\lambda_{m t+1}^{\prime}(0)>0$. Furthermore, by Proposition $1, \lambda_{m t+1}$ is a continuous increasing function of $\lambda_{m t}$ on $[0,1]$. Hence a locally-stable (interior) steady state exists and starting from $\lambda_{m}=0$ the transition to the (first) interior steady state will be monotonic. ${ }^{18}$

Figure 2.3 shows the dynamic evolution of the economy under the assumption that the steady state is unique.

\footnotetext{
${ }^{16}$ Note that $\sum_{j=s, u} p_{u j}^{\prime}\left(\lambda_{m}\right)=0$ follows from the fact that both male types have the same reservation qualities for unskilled women whereas $\sum_{j=s, u} p_{s j}^{\prime}\left(\lambda_{m}\right)>0$ since men born to skilled mothers have a lower reservation quality for skilled women than men born to unskilled mothers.

${ }^{17}$ If this condition does not hold, another steady state is $\lambda_{m}=0$ (which may be locally stable or not). An earlier version of our paper used a directed search model. In that version, despite the fact that some women chose to become skilled when $\lambda_{m}=0$, it was also possible for the economy to get stuck at $\lambda_{m}=0$ since none of these skilled women married and thus did not have sons with different preferences.

${ }^{18}$ There may be other interior steady states as well. A steady-state equilibrium with $\lambda_{m}=1$ is ruled out given that we allow the cost of becoming skilled to be unboundedly large.
} 


\subsection{Discussion}

The predictions of our model are in accordance with several pieces of empirical evidence. First, the model predicts that both women's labor force participation and educational achievement should increase over time. These two variables are well known to have increased steadily over the century (see e.g. Goldin (1990)). Second, the model predicts that over time the attitude of men towards married working women should become more favorable, a pattern that shows up in the poll data we reported. Third, a central prediction of our model is that the fraction of skilled women who marry should increase over time relative to their unskilled counterpart. This pattern holds not only for the college/non-college ratio that we have shown in Figure 1, but also for various alternative definitions of skilled versus unskilled. Lastly, the model predicts that over time the proportion of men born to skilled women should increase. As we show in Figure 2.4, despite potentially complicating factors such as differential fertility across education groups, the proportion of (white) men born to women with college degrees has increased steadily over time. ${ }^{19}$

It should be stressed that although we have chosen to model the transformation of preferences within the household as one that made skilled women more attractive to men with skilled mothers, an alternative would be to model these men as appealing more to skilled women. For example, if a change in male preferences affects the outcome of a bargaining problem in the family (say, over how the woman allocates time between the home and the workplace) so that it becomes more favorable to the skilled woman, then one might expect these men to make more attractive partners for skilled working women. From this perspective, college women remained single in large numbers at the beginning of the century because the men available, by and large, did not make for good partners. ${ }^{20}$ Note that this assumption would have yielded the same predictions. ${ }^{21}$

\footnotetext{
${ }^{19}$ Figure 2.4 is based on 1972-1998 GSS data. It shows the evolution over time of the percentage of white men born to mothers who have at least a college degree. Numbers are obtained for six 10-year birth cohorts. The first cohort includes individuals born between 1910 and 1919, the second cohort includes individuals born between 1920 and 1929 and so forth. In the graph we report the information at each midpoint for the defined cohort intervals. The GSS data set is discussed extensively in the next section.

${ }^{20} \mathrm{An}$ additional incentive for a skilled woman to remain single during the early decades of the 1900s was the existence of marriage bars which made it difficult for women to work once they married (see Goldin (1990) for a discussion).

${ }^{21}$ The data does not allow us to distinguish between the two assumptions since one only observes the marriage outcome and not the rejection decisions of potential matches.
} 
It is worth noting, furthermore, that (following either modelling route) an increase in the fraction of men with skilled mothers would lead to an increase in the number of skilled women even if these men did not prefer them (i.e., they did not have a lower reservation quality for skilled women then men born to unskilled women). We could have allowed for an increase in the proportion of skilled men to change the probability of marriage by a small margin, as long as a skilled woman's utility increased significantly by marrying this type of man. This could happen because a man with a skilled mother takes different actions in the household that particularly favor a skilled woman (e.g., he is more willing to cook and do the laundry and a skilled working woman's time is scarce). That is, the increased attractiveness of being a skilled woman needs not necessarily show up in a large increase in the probability of marriage; it is sufficient that the relative utility of being a skilled woman increases.

\section{Marrying Your Mom: An Empirical Analysis}

In this section we provide evidence for the basic mechanism in our model. We show that a man's probability of marrying a more educated or working woman is affected by the education and work behavior of his mother.

In our model, a greater marriage probability for skilled women increases their return to being skilled. Over time, this leads to a greater proportion of women deciding to become skilled. As more of these women marry, the proportion of men in the population with preferences that favor skilled women likewise increases, leading to further increases in the marriage probability and hence in the proportion of skilled women in the population. While we do not investigate empirically the implications of the increased probability of marriage for women's education and work decisions, we do show that the basic mechanism highlighted in this paper is at work, and that, as claimed by Freud, men indeed tend to marry women who are similar to their mothers. Especially important to our argument, men marry women like their mothers in the two dimensions that most matter to our hypothesis-their education and work behavior.

Our empirical analysis is based on two sets of regressions. In the first we analyze whether the working behavior of a man's mother affects the probability that he marries a woman who also chooses to work. We show that his mother's working behavior has a strong impact on the likelihood that his wife works even after controlling for several characteristics of husband and wife and various other background variables. The second part of the analysis examines the relationship 
between the education of a man's wife and that of his mother. After controlling for several characteristics of the husband, we find that the education of a man's mother has a large and positive effect on how educated his wife is likely to be, whereas the effect of his father's education is quite small and/or insignificant.

\subsection{Data Set and Variable Definitions}

For our analysis we use the General Social Survey (GSS) dataset. The GSS is a series of cross sections that have been collected annually since 1972 (except for a few years) by the National Opinion Research Center. ${ }^{22}$ Each cross section contains about 1500 observations, and respondents are asked about their demographic background, political and social attitudes, and labor market outcomes. For all the survey years, information on the educational attainment of both parents of the respondent are collected. Information on the working behavior of an individual's mother and father was also collected but for a smaller series of years.

In the first part of our analysis we are interested in understanding the determinants of a wife's working behavior, and how this is affected by the working behavior of her husband's mother. For this purpose, we restrict the sample to include all white married men head of households whose wives are between 30 and 50 years of age, as women in this age interval are more likely to have completed their education and are still far from retirement considerations. The working behavior of the wife, our dependent variable in this analysis, is captured by an indicator variable (WIFEWORK) that is equal to one if, during the week preceding the interview, she was employed full time or she had a regular job but was temporarily away from it because of illness, vacation or strike and is equal to zero otherwise. The working behavior of her husband's mother, our variable of interest in this analysis, is described by a dummy variable (MAWORK) that is set equal to one if the man's mother worked for as long as a year after her son was born and before he was 14, and zero otherwise. This variable is only available for the years 1988 and 1994. Hence we restrict our sample to these two years.

We control for several characteristics of the wife that may influence her working behavior such as her age, education, the number of children the husband has ever had (CHILDREN), and the number of children present in the household who are younger than age 6 (BABIES). ${ }^{23}$ Similarly, we control for several characteristics

\footnotetext{
${ }^{22}$ Davis, Smith and Marsden (1999) describes the content and the sampling frame of the GSS.

${ }^{23}$ The number of children is reported in the respondent's questionnaire whereas the number of children under age 6 living in the household is contained in the Household Enumeration Form
} 
of the husband that may influence her work choice, like his age, years of completed education (HUSB EDUC) and income (HUSB INCOME). ${ }^{24}$ We also include in the analysis variables that capture other characteristics of the husband's background: in particular his mother's and father's years of completed education (MAEDUC and PAEDUC), the religion in which he was raised (protestant, catholic, jewish, atheist or other) and whether he considers his family income at age 16 as BELOW, AVERAGE, or ABOVE as compared to the American families in general. ${ }^{25} \mathrm{Fi}$ nally, we include two variables that capture the location in which the husband lived at age 16: the first is a full set of dummy variables indicating the region in which he lived and the second is a set of dummy variables indicating the type of place where he resided. ${ }^{26}$

The summary statistics for our sample are presented in Table 3.1A. The average age of individuals in the sample is 41 for the husband and 38 for the wife, these couples have on average two children, the husband is slightly more educated than the wife (14.5 years of school versus 13.6) whereas his parents have similar average years of education (both 11). Most of the individuals in our sample lived in a city when they were $16.55 \%$ of the men in the sample have a working wife and $51 \%$ of them have a mother who was working while they were growing up. ${ }^{27}$

Table 3.2 describes the working behavior of the wives as function of the working

(HEF). The informations coming from the HEF are more detailed but their quality is inferior (see Methodological Report 73) and the women in our sample belong to different age groups. As a consequence, we include both variables in the analysis.

${ }^{24}$ HUSB INCOME is labor earnings which is provided by the GSS in constant dollars (base=1986) for the period 1974-96. This variable is based on categorical data; income is calculated as the midpoint of the categorical variable.

${ }^{25}$ The GSS provides five categories for self-assessed family income. In addition to those reported there is also "well below" and "well above" average income. Our BELOW category includes "well below" and our ABOVE category includes "well above".

${ }^{26}$ The regional variable includes the following 9 categories: New England (ME, VT, NH, MA, CT, RI), Middle Atlantic (NY, NJ, PA), East North Central (WI, IL, IN, MI, OH), West North Central (MN, IA, MO, ND, SD, NE, KS), South Atlantic (DE, MD, WV, VA, NC, SC, GA, FL, DC), East South Central (KY, TN, AL, MS), West South Central (AR, OK, LA, TX), Mountain (MT, ID, WY, NV, UT, CO, AZ, NM) and Pacific (WA, OR, CA, AK, HI). The residence variable includes the following 6 categories: open country (but not on a farm), farm, small city or town (under 50,000), medium-size city $(50,000-250,000)$, suburb near large city and large city (over 250,000).

${ }^{27}$ Note that working is a different concept for mother and wife as we require the latter to have had a full time job in the week preceding the interview whereas the mother is only required to have worked for a year (full or part time is not specified) at some stage during her son's first 14 years. 
behavior of the men's mothers. Note that having a working mother increases the probability of a man having a wife who works from $49 \%$ to $60 \%$. Table 3.3 describes the wife's working behavior as a function of the type of place where her husband resided when 16 . Note that the wife is more likely to work if her husband resided in the countryside or medium city ( $75 \%$ and $72 \%$, respectively) and least likely to work if he resided in a large city (38\%). Lastly, Table 3.4 describes the wife's working behavior as a function of her own education as well as that of her husband's. A wife's probability of working increases monotonically with her level of education, from around 50\% (high school degree or less) to $62 \%$ (more than college degree). On the other hand, as shown in the next panel of the table, the educational level of the husband first increases and then decreases the probability that his wife works. ${ }^{28}$

The second part of our empirical analysis examines the relationship between the education of a man's wife and that of his mother's. We restrict our attention to married white male head-of-households whose wife is aged 30 to 65 over the period 1975-1994 and where we have information on the education of the man's parents. ${ }^{29}$ Since for this analysis we are pooling across 20 years of surveys, we include not only age but also the husband's birthyear (HUSB BIRTHYR) in order to control for cohort effects. We also define a set of dummy variables to allow for non-linear effects of education. We define education for individuals (WIFE, HUSB, MA, PA,) as HS if they have a high-school degree or COLL if they have at least some years of college, respectively for the wife, the husband, and the husband's mother and father.

Table 3.1B describes the summary statistics for our sample. On average, husbands are 46 years old and wives are 42 years old. Husbands are slightly more educated than wives on average but mothers tend to be more educated than fathers; the correlation between husband's mother and father years of education is .645. Table 3.5 presents information on how wife's education differs by her husband's mother education and by her husband's education, respectively. Men with at least some years of college marry similar women $65 \%$ of the time whereas men without a high-school degree marry women with at least some college only

\footnotetext{
${ }^{28}$ This is most likely due to the fact that the probability of a wife's working decreases with her husband's income (and his education is positively correlated with this) but increases with her education (which is positively correlated with that of her husband's).

${ }^{29}$ Although information on the education of both the respondent's parents and spouse is available for all survey years, we restrict our attention to the period 1975-1994 where information on all the variables we will use in our analysis were collected. In particular, in 1974 the age of the spouse is not reported.
} 
in $9 \%$ of cases; the correlation between husband's and wife's education is equal to .613. Not surprisingly, a more educated mother implies that the son marries a more educated woman. That is, men are most likely to marry a woman with at least some years of college if their mothers have at least some years of college. ${ }^{30}$

\subsection{Results}

This section reports the results of our regression analysis. We show that even after controlling for other characteristics that may influence marital choices such as education, income, religion, region and type of residence, men whose mothers worked are more likely to have a working spouse; men whose mothers were more educated are also more likely to have a more educated spouse. A working mother increases the probability that her son's wife works by a significant degree-from $39 \%$ to $71 \%$. The effect of having a more educated mother is also quantitatively important; having a mother with some years of college increases the probability of obtaining a similarly educated wife by 17 percentage points.

\subsubsection{Working Behavior Analysis}

We investigate the effect of a man's mother working prior to when he was 14 on the probability that his wife works. The probit specification adopted is the following:

$$
D_{i t}^{w}=\beta_{0}+\beta_{1}^{\prime} X_{i t}+\beta_{2} D_{i t}^{m}+\beta_{3} E_{i t}^{m}+\varepsilon_{i t}
$$

where the dependent variable $D_{i t}^{w}$ is an indicator variable that is equal to one if the wife, during the week preceding the interview, was employed full time or if she had a regular job but was temporarily away from it because of illness, vacation or strike and is equal to zero otherwise. $D_{i t}^{m}$ is an indicator variable that is equal to one if the husband's mother worked for at least one year after her son was born and before he turned 14, $X_{i t}$ is a vector of household's characteristics, including the wife's age and education, the number of children, the number of children younger than 6 years, the husband's age, education and income, the education of the husband's mother and father, the religion in which the husband was raised, a self-assessment of his family income (parental), and two sets of dummy variables

\footnotetext{
${ }^{30}$ It is interesting to note that, controlling for other characteristics, a man is equally likely to marry (as compared to remaining single) independently of his mother's working behavior and of her education.
} 
capturing the type and region of residence at age 16. $\varepsilon_{i t}$ is the error term that is assumed to be normally distributed, with zero mean and unit variance. ${ }^{31}$

Regression (i) in Table 3.6 is our baseline regression; it controls only for the characteristics of the wife and children in the household. We next add our main variable of interest-MAWORK. Regression (iii) includes the husband's characteristics and regression (iv) also includes family background variables. Table 3.7 presents the results obtained for model (iv) augmented with the residence and regional variables and also reports the corresponding marginal effects. ${ }^{32}$

We find that the probability that the wife works is positively and significantly related to whether her husband's mother has worked for all specifications. Also significant are the number of children and babies in the household (negative effect), the wife's own education (positive effect) and her husband's income and education (negative effect). From Table 3.7, we find that the presence of an additional baby reduces the probability that the wife works by about 22 percentage points. An additional year of her own education increases the probability that the wife works by about 10 percentage points. A working mother-in-law has a very large effect on the probability that the wife works: the probability increases by some 32 percentage points, from $39 \%$ to about $71 \%$.

The specification in Table 3.7 allows us to distinguish our hypothesis from an alternative one that would argue that men are more likely to marry women who end up working simply because, if their mother worked, then they are more likely to have grown up in a place where many women work. In particular, one might think that women who work in cities are more likely to work, either because of social norms, self-selection or greater opportunity. Although we find some of the residence and regional dummies to be significant, MAWORK remains positive and significant at the $1 \%$ level.

We also control for religion since men may tend to marry women from the same religion and, if religion and work are correlated, then this may be responsible for the positive coefficient on MAWORK. Controlling for religion (coefficients not reported in table) does not affect our results.

Lastly, it may be argued that a mother is more likely to have worked if her

\footnotetext{
${ }^{31}$ All probit regressions are run including a constant and sample year and estimated using robust standard errors. For expositional purposes the coefficient on the constant term and the sample year effect are not reported.

${ }^{32}$ In the regressions, the omitted variables are OTHER for the husband's religion dummies, BELOW for his income self-assessment, COUNTRY for his place of residency at 16, and East South Central for the regional dummies.
} 
family income was low, leading in the future to lower wealth for her son (via bequests or other channels of wealth persistence). If, in turn, lower family wealth makes it more likely that the son's wife works, then the positive coefficient on MAWORK may simply be picking up the negative correlation between family wealth and the wife's working behavior. Unfortunately, our data set does not have any information on the son's parental wealth or income. The best we could do was to include a measure of the parents' income/wealth (compared to that of the average American family) as assessed by the son. This variable is not significant once we control for parental education and in all specifications does not affect our results.

All the results are robust to alternative definitions of the dependent variable: whether we define a wife as working when she works full time or part time, or when she works more than 40 hours per week, we obtain similar results. Adding squared terms for the husband's age, the wife's age and the husband's income also leaves our results unchanged. On the other hand, if we use as indicator of the husband's mother working history not whether she worked for as long as a year in the years between when her son was born and when he turned 14, but instead whether she worked for a long as a year at any point after marriage, the results no longer hold and the coefficient on the husband's mother's work becomes insignificant. This is most likely resulting from the fact that most mothers have worked for at least a year at some point during their married life. A last alternative, whether the man's mother worked after he was born and before he started first grade, also has the mother's working behavior entering positively and significantly in determining the probability that the son's wife works. ${ }^{33}$

\subsubsection{Education Analysis}

We next turn to our analysis of the relationship between the education of a man's wife and that of his mother's. We choose a similar specification as in the work regression:

$$
E_{i t}^{s}=\beta_{0}+\beta_{1}^{\prime} X_{i t}+\delta_{1} E_{i t}^{m}+\delta_{2} E_{i t}^{f}+\varepsilon_{i t}
$$

\footnotetext{
${ }^{33}$ It would have been interesting to also examine how characteristics of the wife's mother affect her decision to work as well. We are not able to do so, unfortunately, since the GSS reports information only on the working history of the repondent's mother and spouse, but not on the spouse's parents.
} 
where $E_{i t}^{s}$ represents husband $i$ 's wife's years of completed education; $X_{i t}$ is a matrix of explanatory variables including the husband's age, his birth year, his earnings, education, the religion he was raised in, his self-assessment of his family income at age 16, the type of place he lived in when he was 16, and the region he lived in at age $16 ; E_{i t}^{m}$ and $E_{i t}^{f}$ represent years of completed education for the husband's mother and father respectively and $\varepsilon_{i t}$ is an error term that is assumed to be normally distributed, with zero mean and unit variance. In order to control for the presence of non-linear age or income effects, we also include quadratic terms in husband's age (HUSB AGE2), birth year (HUSB BIRTHYR2), and income (HUSB INCOME2) in the regression. The estimates are obtained by using robust standard errors. Our hypothesis would imply that $\delta_{1}$ is positive and statistically significant, and larger in magnitude than $\delta_{2}$. In the regressions, the omitted variables are OTHER for the husband's religion dummies, BELOW for his income self-assessment, COUNTRY for his place of residency at 16, and East South Central for the regional dummy.

The results for the linear regression are presented in Table 3.8. The baseline regression includes only the husband's characteristics as explanatory variables. In regressions (ii), (iii) and (iv) we add, respectively, the education of the husband's mother, the education of his father, and lastly both parental education variables. In regression (v) we add to specification (iv) two other background variables, the religion he was raised in and his self-assessment of family income, and square terms in husband's age, birth year and income. Finally, in regression (vi) we also add the residence and the regional dummy variables. Including the residence variable should allow us to at least partially distinguish between the competing hypothesis that a man with a more educated mother is more likely to have a more educated wife simply because there were more educated women in the area in which he lived.

As shown in Table 3.8, the husband's education is a strong, positive and significant determinant of his wife's education. Husband's income is also positive and significant (although at the $10 \%$ level), for regressions (iii) to (v), as is the coefficient on the husband's birth year (regressions (i) through (iv)). Column (ii) shows that, conditional on her husband's characteristics, a wife's education increases with the husband's mother's education. In particular, an additional year of education for the mother-in-law would increase the wife's education by about $8 \%$ of a year. So, the presence of a mother-in-law with a college degree would, ceteris paribus, predict that the wife's education would be about 4 months 
greater relative to a mother-in-law with only a high school diploma. ${ }^{34}$

Column (iii) shows that the husband's father education is positive and significant, although about half the size of the coefficient on mother's education found in column (ii). However, when we include both the mother and father's education in the regression, column (iv), we find that only the coefficient on the mother's education is statistically significant. Moreover, these coefficients are statistically different from one another at the five percent significance level. A similar result holds true when we add the husband's religion, his family income at 16, and square terms in husband's age, birth year, and income (regression (v)). This is the specification with the highest predictive power. In this case, the coefficient on mother's education is one order of magnitude larger than the coefficient on father's education and we can reject at the one percent significance level the null hypothesis that the mother's and father's education levels have equal effects. As shown in column (v) none of the background variables included in the analysis are statistically significant. The asymmetry between mother and father education is also found when we add the location variables, regression (vi).

The asymmetry in the significance of the coefficients on mother's and father's education is important since otherwise one might think that these variables were picking up some other characteristics of the son, such as the quality of his education or his income, for which our variables are noisy measures. It is also worth noting that it is not the case that mother's education is a better signal of her son's earnings than father's education. We ran a log wage regression on husband's characteristics and parental education and found that the mother's education is never significant whereas the coefficient on the father's education is relatively small (and becomes insignificant when we include square terms and residence variables). ${ }^{35}$

We have also run a series of ordered probit regressions for the same specification to estimate the effect of parental education on non-linear categories of the wife's education. In this case we defined the dependent variable as $e_{i t}=1$ if the wife

\footnotetext{
${ }^{34}$ The magnitude of this effect is quite large, especially if compared to the effect of parents' education on their own children's education that is found in the literature. In particular, Card and Lemieux (2000), using the same data set find that one more year of parental education increases a child's education by about $20 \%$ of a year.

${ }^{35}$ We have also studied whether women's marital choices are characterized by a similar asymmetry in the importance of same-sex and opposite-sex parents. We find that both mother's education and father's education are equally important determinants of the education of their daughter's husband. Although we do not report these results here, they are available upon request from the authors.
} 
has less than high school, $e_{i t}=2$ if she completed high school, and $e_{i t}=3$ if she completed at least some years of college. We also recoded both the husband's education and the parents' education according to the same specification. As in the linear regression, we study the effect of the parents-in-law's education on the wife's education after controlling for the husband's characteristics. ${ }^{36}$

The results for the ordered probit regressions are summarized in Tables 3.9 and 3.10. We present the results in a similar way to the linear regression. We report the marginal effects associated with the specification that has the highest predictive power (regression (v)) in Table 3.10. ${ }^{37}$ In this table the first two columns present the actual probit estimates for model (v) and the associated robust standard errors. The third column shows the estimated marginal effects of the explanatory variables on the probability that the wife has less than a high school diploma (i.e. the first outcome) and the fourth column presents the estimated marginal effects on the probability that the wife has at least some years of college (the third outcome for the wife's education recode). ${ }^{38}$ The marginal effect for the second outcome can be found as a residual. ${ }^{39}$

\footnotetext{
${ }^{36}$ The interpretation of the regression parameters for the ordered probit is as follows. If for a particular regressor the parameter estimate is positive, then a higher value of the variable lowers the likelihood of the first outcome (that is, the probability that the spouse has less than a high school diploma) and increases the likelihood of the third outcome (that is, that the spouse has at least some years of college). The effect on the probability of the second outcome is ambiguous.

${ }^{37}$ We choose not to report the results obtained for the specification that also includes the location dummies (Model (vi)) since, similarly to what found for the linear regression, it has a lower explanatory power than Model (v) and Model (iv). The results for our variables of interest are robust to the introduction of the location variables.

${ }^{38}$ The marginal probabilities for the model are the following:

$$
\begin{aligned}
& \operatorname{Pr}\left(e_{i t}=1\right)=\operatorname{Pr}\left(\varepsilon_{i t} \leq-\gamma^{\prime} Z_{i t}\right)=\Phi\left(-\gamma^{\prime} Z_{i t}\right) \\
& \operatorname{Pr}\left(e_{i t}=2\right)=\operatorname{Pr}\left(-\gamma^{\prime} Z_{i t}<\varepsilon_{i t} \leq \mu-\gamma^{\prime} Z_{i t}\right)=\Phi\left(\mu-\gamma^{\prime} Z_{i t}\right)-\Phi\left(-\gamma^{\prime} Z_{i t}\right) \\
& \operatorname{Pr}\left(e_{i t}=3\right)=\operatorname{Pr}\left(\varepsilon_{i t}>\mu-\gamma^{\prime} Z_{i t}\right)=1-\Phi\left(\mu-\gamma^{\prime} Z_{i t}\right)
\end{aligned}
$$
}

where $\Phi$ is the cumulative distribution function for a standard normal distribution, $Z_{i t}$ is a vector of regressors that includes husband's characteristics $\left(X_{i t}\right)$, and parent's education $\left(E_{i t}^{m}\right.$ and $\left.E_{i t}^{p}\right)$, and $\gamma$ is a parameter vector $\left(\gamma=\left(\beta, \delta_{1}, \delta_{2}\right)\right)$. Note that the three probabilities must add to one. The threshold parameter $\mu$ is estimated together with the vector of parameters $\gamma$.

${ }^{39}$ The marginal effects are computed at the mean for our sample for continuous variables; for dummy variables it is computed as the difference $\Phi(D=1)-\Phi(D=0)$, where $\Phi$ is the standardized normal cdf. 
We find similar results as for our linear regressions. The husband's education and income are always strong and significant (at the 1 percent level) determinants of his wife's education. In addition, in the non-linear case, whether the husband was raised in the Jewish religion is also a positive and significant determinant of his wife's education. Moreover, we continue to find the effects of husband's mother and father education on the education of his wife asymmetric (although in this case we cannot reject the assumption that father education does not matter). Note that the presence of a mother with at least some college increases the likelihood of a wife with the same level of educational attainment by 17 percentage points whereas one with a high school diploma increases the probability of the same outcome by 10 percentage points. The effect of a father with at least some college is significant and it increases the likelihood of a wife with at least some college by 10 percentage points. However, we can statistically reject the assumption that mother and father are equally important determinants of the wife's education at the $5 \%$ significance level.

In our education regressions we are including individuals from many different cohorts. It is plausible that the way in which parental education and the wife's education are correlated has changed significantly over time in a way that is not captured by a linear birth year effect. In order to investigate this question more in depth, we construct three different fifteen-year birth cohorts. Cohort I includes males born between 1915 and 1929, Cohort II consists of men born between 1930 and 1944, and Cohort III includes men born between 1945 and 1959. Summary statistics of our data are presented in the appendix.

We ran both the linear and the ordered probit regressions separately for each cohort, creating our sample, as described previously, by pooling from the cross sectional data those men who were born within the defined time interval. Our results show that for all cohorts, the husband's education and income are a strong and significant determinant of his wife's education. Moreover, for the linear specification, we find the asymmetry between mother and father education for every cohort. The husband's mother's education is always a significant determinant of the wife's education whereas the father's education is not. However, for the non-linear specification we find that the relative importance of mother and father substantially changed over time. In this case, for the first two cohorts, only mother's education is statistically significant. However, for the most recent cohort, Cohort III, both mother's and father's education are statistically significant. In particular, either the mother or father having at least some college equally increases the probability of marrying a woman with at least some college. 
Table 3.11 summarizes the estimated marginal effects of our explanatory variables on the probability that the wife has less than a high school diploma, or some years of college across cohorts for model (v). ${ }^{40}$ In this table the first three columns present the estimated marginal effects of the explanatory variables on the probability that the wife has less than a high school diploma (i.e. the first outcome) for Cohort I, II, and III respectively. Similarly, the last three columns present the estimated marginal effects on the probability that the wife has at least some years of college (the third outcome for the wife's education recode).

For Cohort I the presence of a mother-in-law with a high school diploma statistically increases the probability that the wife has at least some years of college by about 10 percentage points, whereas the probability increases by 13 percentage points if she has at least some college. For the second Cohort a mother with at least some college increases the likelihood of a wife with the same level of educational attainment by about 16 percentage points whereas one with a high school diploma increases the probability of the same outcome by 10 percentage points. For both cohorts, the effect of the father is much smaller and not significant. Finally, for the third cohort the presence of a mother with at least some college increases the likelihood of a wife with some college by 15 percentage point. However, for this cohort the effect of a father with at least some college becomes significant and equal in size to the effect of a similarly educated mother (14 percentage points).

\section{Conclusion}

Over the last century, society has been deeply transformed: not only is women's economic role radically different, but a new family model has emerged and individuals' expectations and preferences toward marriage and gender roles have evolved in important ways. If, at the beginning of the century, the vast majority of men did not consider it appropriate for a married woman to work and women were predominantly housewives with lower levels of education than men, today most men approve of married women who work, women graduate from college at a higher rate than men, and women are able to combine, for the most part,

\footnotetext{
${ }^{40}$ Model (v) has the highest predictive power for both Cohort II and Cohort III. However, for the first cohort, the regression that also includes location variables, Model (vi), has the highest predictive power (although the estimates of the parameters of interest are unaltered). We choose to report the results obtained for Model (v) in order to allow comparisons across cohorts.
} 
marriage and a career. ${ }^{41}$

Standard explanations of the changed economic role of women have abstracted from this change in attitudes and have focused on technological factors: the introduction of time-saving consumer durables that reduced the time required to carry out traditional tasks in the household, the advent of the pill that enabled women to control fertility, and the shift toward a service and skill-intensive economy that increased the proportion of jobs suitable for women.

In this paper we abstract from technological change and bring the role of preferences to the forefront. Our paper argues that the spread of different preferences can be an important determinant of the last century's profound transformation of the economy in terms of observed marriage patterns, attitudes and women's economic role. We propose that male preferences evolved over time through increased exposure to a new family model in which the woman played a different role. Having a different type of mother affected a son's preferences, increasing his probability of marrying a skilled/working woman. This mechanism, which is in accordance with a psychological and sociological literature that claims that individuals tend to replicate the patterns they experienced in their family of origin, provides a new perspective on our society's evolution: at the beginning of the century a large fraction of skilled women remained single (compared to their less educated counterpart) and most women did not invest in higher education and when married tended not to work. Nonetheless, the few educated women who did marry, work and have children set a new role model for their sons so that the next generation of men was characterized by a higher fraction who preferred a skilled wife. Thus, generation by generation, the economy was gradually transformed: men's preferences evolved, marriage patterns changed and women in higher number entered college, decided to work and were able to combine family and career.

We construct a model that allows us to study the dynamic diffusion of these new preferences in society and which generates predictions that are in accordance with the patterns found in the data. In our framework, male preferences influence women's education and labor decisions through their effect on women's marital prospects. Men with skilled working mothers prefer similar women. The endogeneous diffusion of these preferences in society over time is determined by the marriage patterns and education decisions that emerge in equilibrium. We show

\footnotetext{
${ }^{41}$ The extent to which professional women are able to successfully combine children and a career is currently the topic of hot debate as witnessed by the success of the recent book by Hewlett.
} 
that, starting from a situation in which there is only a small proportion of this "new" type of men, the economy evolves monotonically towards its steady state. During the transition path, marriage patterns and attitudes change so that skilled women are more likely to marry than previously, more women become educated, and female labor force participation increases.

Our empirical work supports the mechanism that the model highlights. Using the GSS, we provide evidence that men whose mothers were educated or worked are, ceteris paribus, more likely to marry women who also are educated and work. Men do indeed tend to marry women who are similar to their mothers in these two important dimensions. We show that this is true even after controlling for other factors that may influence marital choices such as education, income, religion, region and type of residence. Having a mother who works increases the probability that the son's wife works by a significant degree-from $39 \%$ to $71 \%$. The effect of having a more educated mother is also quantitatively important; a mother with some years of college increases the probability of obtaining a similarly educated wife by 17 percentage points.

We see many possible directions for future research. It would be of interest, for example, to quantitatively assess the contribution of this new preference channel relative to changed behavior brought about by increased female wages or through the technological channels mentioned previously. Investigating variation in women's labor force participation across US states or across countries (initially due to, say, an "exogenous" factor such as different mobilization rates of men in World War II), may also allow us to examine whether the macroeconomic evidence supports our hypothesis. We leave these questions for further research.

\section{References}

[1] Altonji, J. and R. Blank, "Race and Gender in The Labor Market" in O. Ashenfelter and D. Card, eds., Handbook of Labor Economics, Vol. 3, Elsevier Science B.V., 3143-3259

[2] Bisin, A. and T. Verdier (2000), "Beyond the Melting Pot: Cultural Transmission, Marriage, and the Evolution of Ethnic and Religious Traits," Quarterly Journal of Economics, CXV(3), 955-988, 2000.

[3] Blau F. and Kahn L.(2000), "Gender Differences in Pay", Journal of Economic Perspectives, Fall, 14:75-99 
[4] Card D. and Lemieux (2000), "Dropout and Enrollment Trends in the PostWar Period: What Went Wrong in the 1970s?" NBER Working Paper 7658.

[5] Costa D. (2000), "From Mill Town to Board Room: The Rise of Women's Paid Labor", Journal of Economic Perspectives, Fall, 14: 101 - 122

[6] Davis J.A., Smith T. W., and Marsden P. V. (1999), General Social Surveys, 1972-1998: Cumulative Codebook. Chicago: NORC

[7] Del Boca D., Locatelli M. and S. Pasqua (2000), "Employment Decisions of Husbands and Wives," Labour, 1, 14

[8] Erskine H. (1971), "The Polls: Women's Role" Public Opinion Quarterly, Vol. 35, No. 2., pp. 275-290.

[9] Fernández, R., Guner, N. and J. Knowles (2001), "Love and Money: A Theoretical and Empirical Analysis of Household Sorting and Inequality" NBER Working Paper 8580.

[10] Fernández, R. and R. Rogerson (2001), "Sorting and Long-Run Inequality," Quarterly Journal of Economics, 116 (4), 1305-1341, 2001.

[11] Fogli, A. (2000), "Labor Market Rigidities and Family Ties," Ph.D thesis, University of Pennsylvania.

[12] Freud S., Some Psychological Consequences of the Anatomical Distinction Between the Sexes In J. Strachey (Ed. and Trans) Standard Edition (Vol. 8, pp 133-142) London: Hogart Press

[13] Galor, O and O. Moav, "Natural Selection and the Origin of Economic Growth," Quarterly Journal of Economics, 117, forthcoming, 2002.

[14] Galor O. and Weil D. N.(1996), "The Gender Gap, Fertility and Growth," American Economic Review 86: 374-387

[15] Geher G. (2000), "Perceived and Actual Characteristics of Parents and Partners: A Test of a Freudian Model of Mate Selection" Current Psychology: Developmental, Learning, Personality, Social 19 (3)

[16] Goldin C. (1997), "Career and Family: College Women Look at the Past," in , F. Blau and R., Gender and Family in the Workplace, F. Blau and R. Ehrenberg, eds., New York: Russell Sage Press, 20-58. 
[17] Goldin C. (1990), Understanding the Gender Gap. Oxford University Press

[18] Goldin C. and Katz L. (2000), "The Power of the Pill: Oral Contraceptives and Women's Carrier and Marriage Decisions", NBER Working Paper, \# 7527

[19] Greenwood J., Seshadri A., and Yorukoglu M. (2001), "Engines of Liberation," University of Rochester, mimeograph.

[20] Hewlett, Sylvia Ann (2002), "Creating a Life: Professional Women and the Quest for Children"

[21] Jones L., McGrattan E. and Manuelli R. E. (2001), "Why are Married Women Working So Much?," University of Minneapolis, mimeograph

[22] Killingsworth M.R. and Heckman J. (1986) "Female Labor Supply: A Survey," Chapter 2 in Handbook of Labor Economics, Ashenfelter O. and Layard R., eds., North Holland

[23] Kremer, M. (1997), "How Much Does Sorting Increase Inequality," Quarterly Journal of Economics, CXII, 115-139.

[24] Lundberg S. and Pollak R. (2001), "Efficiency in Marriage", University of Washington, mimeo

[25] Olivetti C. (2001), "Changes in Women's Hours of Market Work: The Effect of Changing Returns to Experience," Boston University, mimeograph

[26] Pencavel, J. (1998), "The Market Work behavior and Wages of Women, 197594," Journal of Human Resources, 38:4, 771-804.

[27] Thornton A., Alwin D. F., and Camburn D. (1983), "Causes and Consequences of Sex-Role Attitudes and Attitude Change", American Sociological Review, 48 (2): 211-227

[28] Wilkie, J. R. (1988), "Marriage, Family Life, and Women's Employment." in Women Working, 2d ed., Stromberg A. H. and Harkess S. eds., Mountain View, CA: Mayfield, 149-66

[29] Wilson G.D. and Barrett P.T. (1987), "Parental Characteristics and Partner Choice: Some Evidence of Oedipal Imprinting", Journal of Biosocial Science, 19: $157-161$ 
Figure 1 Ratio of Percentage Never-Married Individuals with College Degree to Percentage Never-Married Individuals with No College.

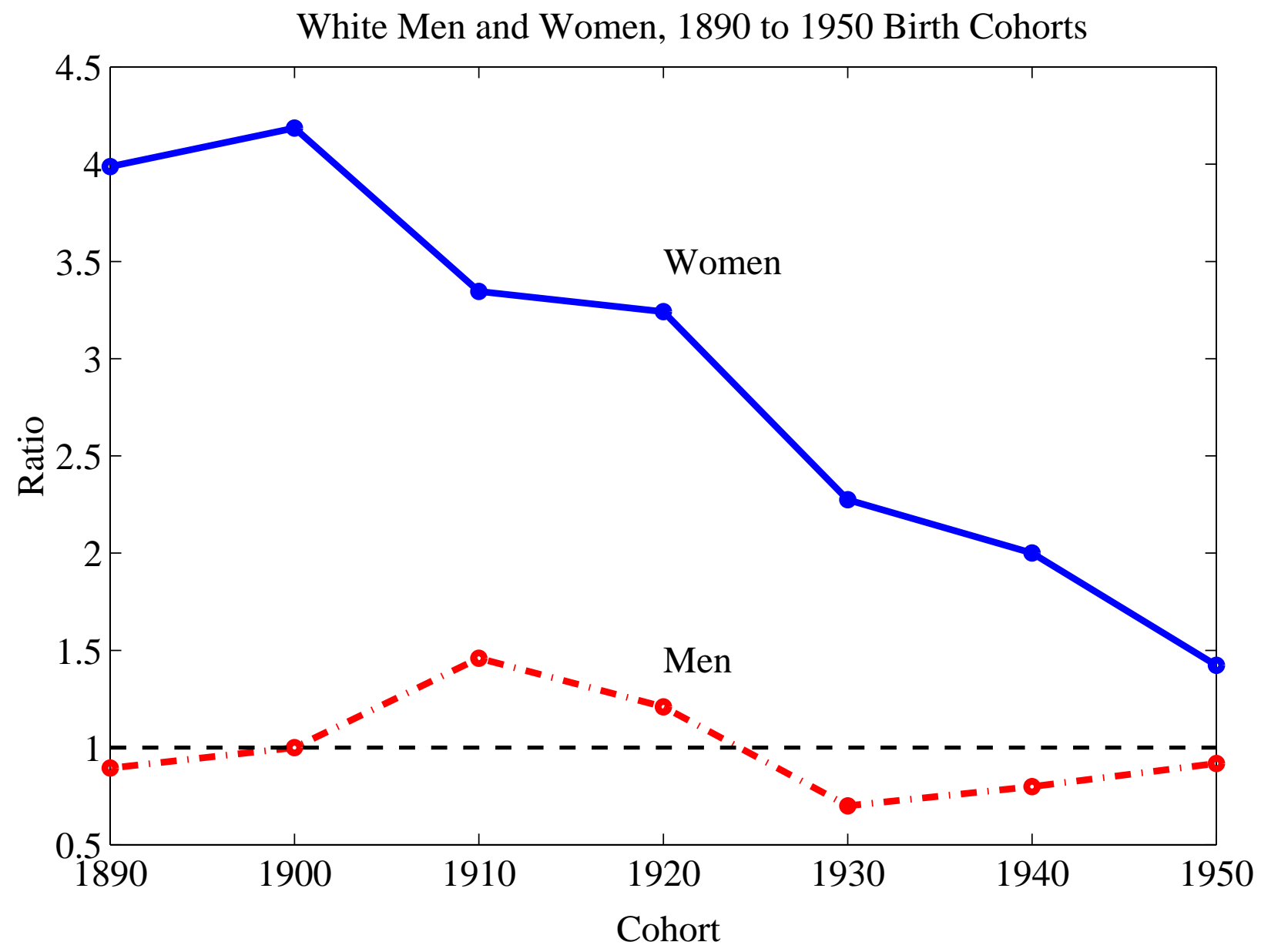

Source: CPS March Supplemental Files (1965, 1970, 1980, 1990, 1999).

Goldin (1995), Table 2, for 1890 and 1900 Birth Cohorts. 
Figure 2.1 Husband's Utility as a Function of Wife's Wage

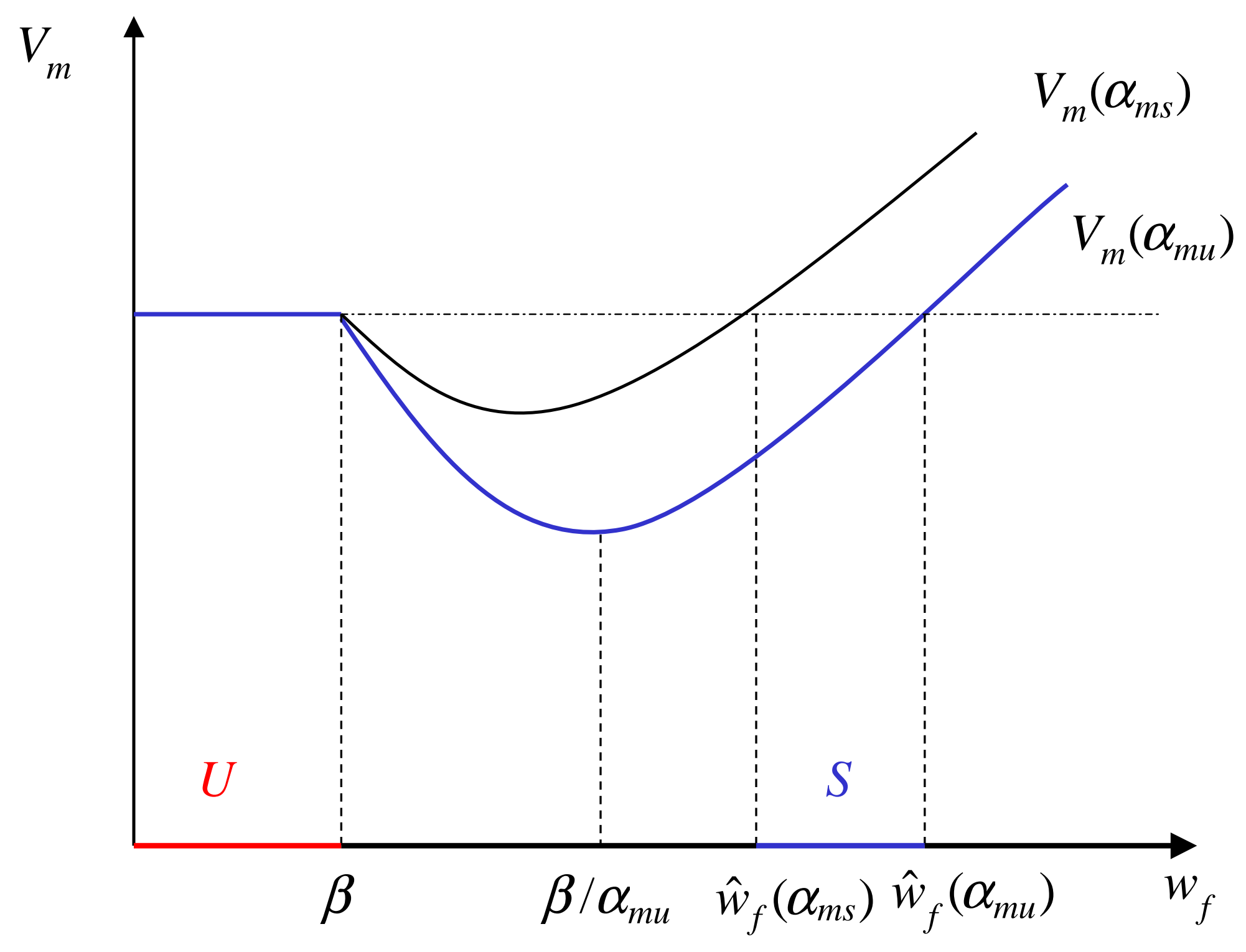


Figure 2.2

Equilibrium

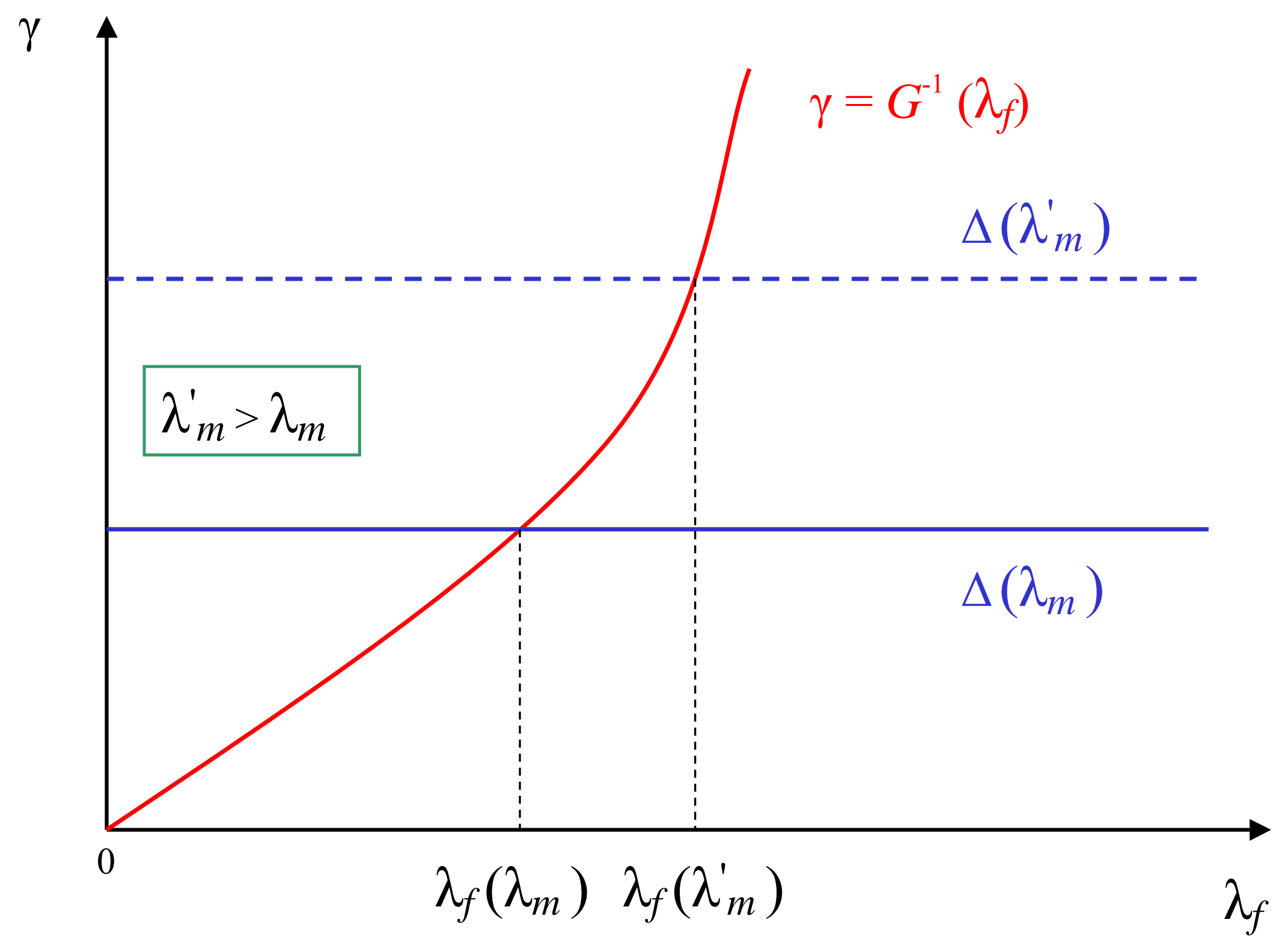


Figure 2.3

Dynamics

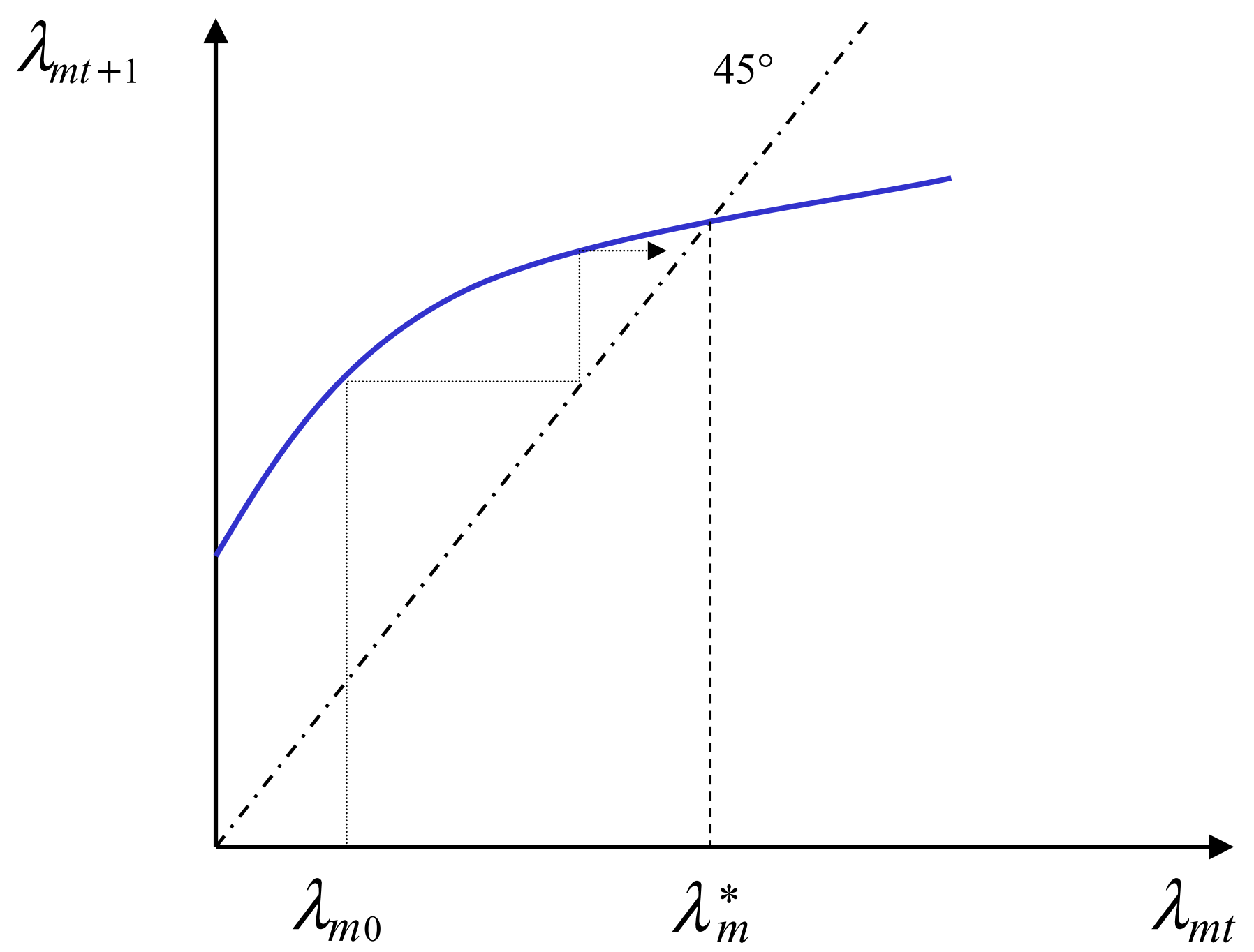


Figure 2.4 Percentage of Men Born to Women with College Degree White Men, 1915 to 1965 Birth Cohorts

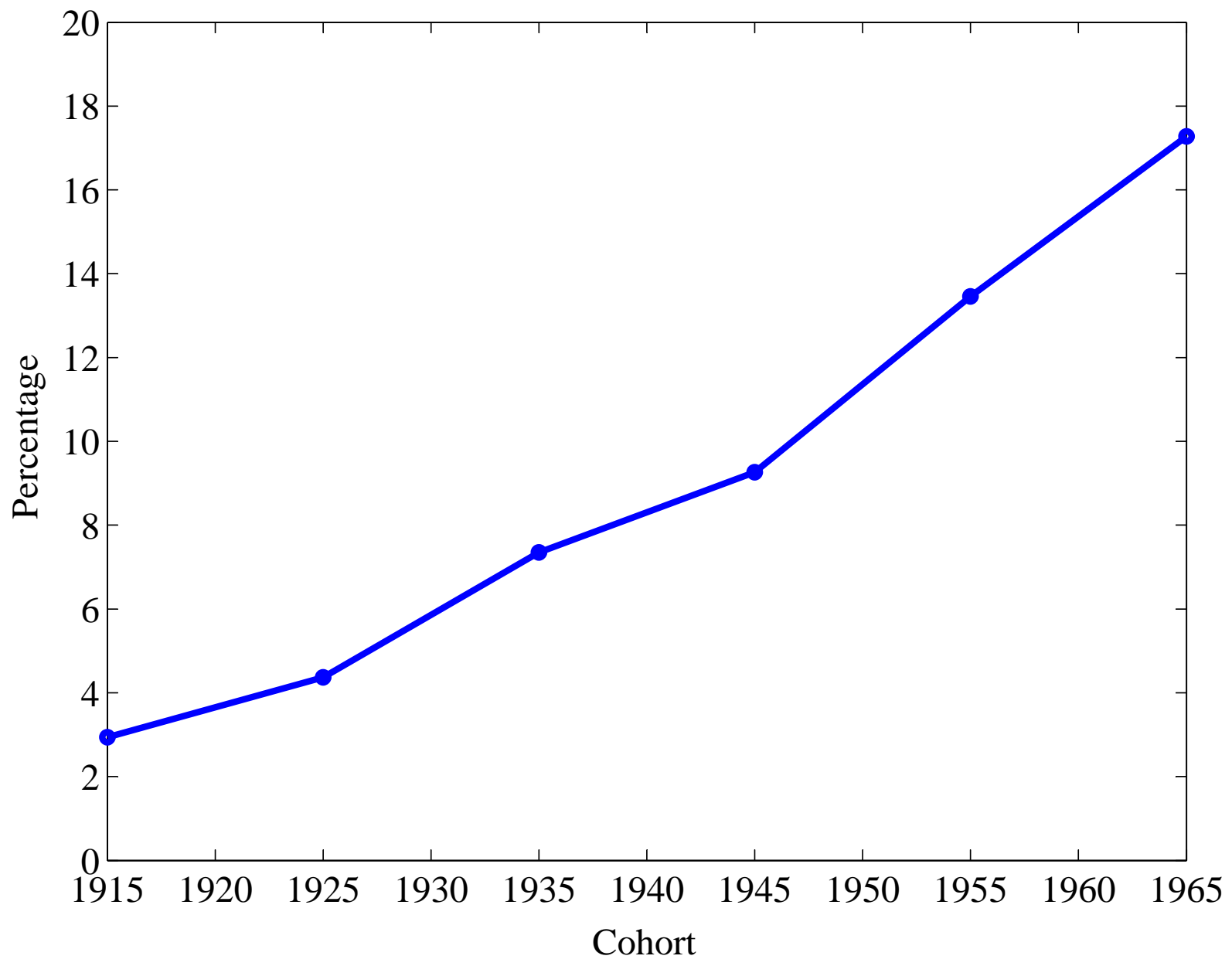

Source: General Social Survey (GSS) data, 1972-1998 
Table 3.1A Summary Characteristics in the Work Regression

\begin{tabular}{|c|c|c|c|}
\hline Variable & $\begin{array}{l}\text { Sample Means } \\
\text { (Std. Dev.) }\end{array}$ & Variables & Sample Means \\
\hline \multirow[t]{2}{*}{ WIFEWORK } & .547 & PROTESTANT & .610 \\
\hline & & CATHOLIC & .314 \\
\hline \multirow[t]{2}{*}{ MAWORK } & .509 & JEWISH & .019 \\
\hline & & ATHEIST & .038 \\
\hline \multirow[t]{2}{*}{ WIFE AGE } & 37.96 & BELOW & .233 \\
\hline & $(5.57)$ & AVERAGE & .579 \\
\hline \multirow[t]{2}{*}{ WIFE EDUC } & 13.59 & ABOVE & .189 \\
\hline & $(2.39)$ & COUNTRY & .126 \\
\hline \multirow[t]{2}{*}{ CHILDREN } & 2.17 & FARM & .101 \\
\hline & $(1.38)$ & SM CITY & .390 \\
\hline \multirow[t]{2}{*}{ BABIES } & .365 & MED CITY & .157 \\
\hline & $(.688)$ & SUBURBS & .145 \\
\hline \multirow[t]{2}{*}{ HUSB AGE } & 41.09 & LG CITY & .082 \\
\hline & $(6.55)$ & NEW ENGLAND & .038 \\
\hline \multirow[t]{2}{*}{ HUSB EDUC } & 14.50 & MID. ATLANTIC & .201 \\
\hline & $(2.93)$ & E.N. CENTRAL & .233 \\
\hline \multirow[t]{2}{*}{ HUSB INCOME } & 33189.77 & W.N. CENTRAL & .088 \\
\hline & $(21204.86)$ & S. ATLANTIC & .126 \\
\hline \multirow[t]{2}{*}{ MAEDUC } & 11.36 & E.S. CENTRAL & .057 \\
\hline & $(3.13)$ & W.S. CENTRAL & .132 \\
\hline \multirow[t]{2}{*}{ PAEDUC } & 11.18 & MOUNTAIN & .063 \\
\hline & $(3.81)$ & PACIFIC & .063 \\
\hline \multicolumn{2}{|c|}{ Number of observations } & & 191 \\
\hline
\end{tabular}


Table 3.1B Summary Characteristics in the Education Regression

\begin{tabular}{|c|c|c|c|}
\hline Variable & $\begin{array}{c}\text { Sample Means } \\
\text { (Std. Dev.) }\end{array}$ & Variables & Sample Means \\
\hline \multirow[t]{2}{*}{ HUSB INCOME } & 35713.89 & PROTESTANT & .652 \\
\hline & $(25722.35)$ & CATHOLIC & .284 \\
\hline \multirow[t]{2}{*}{ HUSB AGE } & 45.67 & JEWISH & .028 \\
\hline & $(9.89)$ & ATHEIST & .028 \\
\hline \multirow[t]{2}{*}{ HUSB BIRTHYR } & 1939 & BELOW & .275 \\
\hline & $(11.8)$ & AVERAGE & .530 \\
\hline \multirow[t]{2}{*}{ HUSB EDUC } & 13.62 & ABOVE & .195 \\
\hline & $(3.07)$ & COUNTRY & .113 \\
\hline \multirow[t]{2}{*}{ WIFE AGE } & 42.51 & FARM & .203 \\
\hline & $(9.17)$ & SM CITY & .332 \\
\hline \multirow[t]{2}{*}{ WIFE EDUC } & 13.08 & MED CITY & .132 \\
\hline & $(2.45)$ & SUBURBS & .099 \\
\hline \multirow[t]{2}{*}{ MAEDUC } & 10.44 & LG CITY & .121 \\
\hline & $(3.32)$ & NEW ENGLAND & .061 \\
\hline \multirow[t]{2}{*}{ PAEDUC } & 9.88 & MID ATLANTIC & .182 \\
\hline & $(4.07)$ & E.N. CENTRAL & .235 \\
\hline HUSB HS & .315 & W.N. CENTRAL & .105 \\
\hline HUSB COLL & .533 & S. ATLANTIC & .141 \\
\hline WIFE HS & .442 & E.S. CENTRAL & .063 \\
\hline WIFE COLL & .426 & W.S. CENTRAL & .077 \\
\hline MAHS & .396 & MOUNTAIN & .052 \\
\hline MACOLL & .152 & PACIFIC & .084 \\
\hline PAHS & .248 & & \\
\hline PACOLL & .191 & & \\
\hline \multicolumn{2}{|c|}{ Number of observations } & & 2368 \\
\hline
\end{tabular}


Table 3.2 : W if e's Working Behavior by Mother's Working Behavior

\begin{tabular}{|c|c|c|c|}
\hline \multirow[t]{2}{*}{ WIFEWORK } & \multicolumn{2}{|c|}{ MAWORK } & \multirow[t]{2}{*}{$\%$ in population } \\
\hline & $\mathrm{NO}$ & YES & \\
\hline NO & 51.28 & 39.51 & 45.28 \\
\hline YES & 48.72 & 60.49 & 54.72 \\
\hline Total & 100 & 100 & \\
\hline$\%$ in population & 49.06 & 50.94 & \\
\hline
\end{tabular}

Table 3.3: W if e's Working Behavior by Husband's Residence at Age 16

\begin{tabular}{lcccccc}
\hline \hline & \multicolumn{7}{c}{ HUSBAND'S RESIDENCE } \\
WIFEWORK & Country & Farm & Sm City & Med City & Suburbs & Lg City \\
& 25.00 & 43.75 & 50.00 & 28.00 & 60.87 & 61.54 \\
NO & 75.00 & 56.25 & 50.00 & 72.00 & 39.13 & 38.46 \\
YES & 100 & 100 & 100 & 100 & 100 & 100 \\
Total & & & & & & \\
& 12.58 & 10.06 & 38.99 & 15.72 & 14.47 & 8.18 \\
\hline in population & & & & & & \\
\hline \hline
\end{tabular}


Table 3.4: W if e's Working B ehavior by Own and Husband's E ducation

\begin{tabular}{|c|c|c|c|c|}
\hline \multirow[t]{2}{*}{ WIFEWORK } & \multicolumn{4}{|c|}{ WIFE'S EDUCATION } \\
\hline & Less or equal HS & Some College & College & More than College \\
\hline NO & 50.00 & 42.11 & 40.00 & 38.10 \\
\hline YES & 50.00 & 57.89 & 60.00 & 61.90 \\
\hline Total & 100 & 100 & 100 & 100 \\
\hline$\%$ in population & 50.31 & 23.90 & 12.58 & 13.21 \\
\hline \multirow[t]{2}{*}{ WIFEWORK } & \multicolumn{4}{|c|}{ HUSBAND'S EDUCATION } \\
\hline & Less or equal HS & Some College & College & More than College \\
\hline NO & 46.30 & 42.11 & 41.67 & 51.61 \\
\hline YES & 53.70 & 57.89 & 58.33 & 48.39 \\
\hline Total & 100 & 100 & 100 & 100 \\
\hline$\%$ in population & 33.96 & 23.90 & 22.64 & 19.50 \\
\hline
\end{tabular}


Table 3.5 Wife Education By Husband's Mother and Husband's Education

\begin{tabular}{|c|c|c|c|c|}
\hline \multirow[t]{2}{*}{ WIFE'S EDUCATION } & \multicolumn{3}{|c|}{ HUSBAND'S MOTHER EDUCATION } & \multirow[b]{2}{*}{$\%$ in population } \\
\hline & Less than HS & HS & At least some College & \\
\hline Less than HS & 21.72 & 7.56 & 3.05 & 13.26 \\
\hline HS & 52.25 & 40.89 & 28.81 & 44.17 \\
\hline At least some College & 26.03 & 51.54 & 68.14 & 42.57 \\
\hline Total & 100 & 100 & 100 & \\
\hline$\%$ in population & 45.11 & 39.65 & 15.24 & \\
\hline \multirow[t]{2}{*}{ WIFE'S EDUCATION } & \multicolumn{3}{|c|}{ HUSBAND'S EDUCATION } & \\
\hline & Less than HS & HS & At least some College & $\%$ in population \\
\hline Less than HS & 48.47 & 12.72 & 3.57 & 13.26 \\
\hline HS & 42.62 & 66.53 & 31.38 & 44.17 \\
\hline At least some College & 8.91 & 20.75 & 65.06 & 42.57 \\
\hline Total & 100 & 100 & 100 & \\
\hline$\%$ in population & 15.16 & 31.54 & 53.30 & \\
\hline
\end{tabular}


TABle 3.6 Probit Whether WIFE WORKS ON MOTHER'S WORKING BEHAVIOR

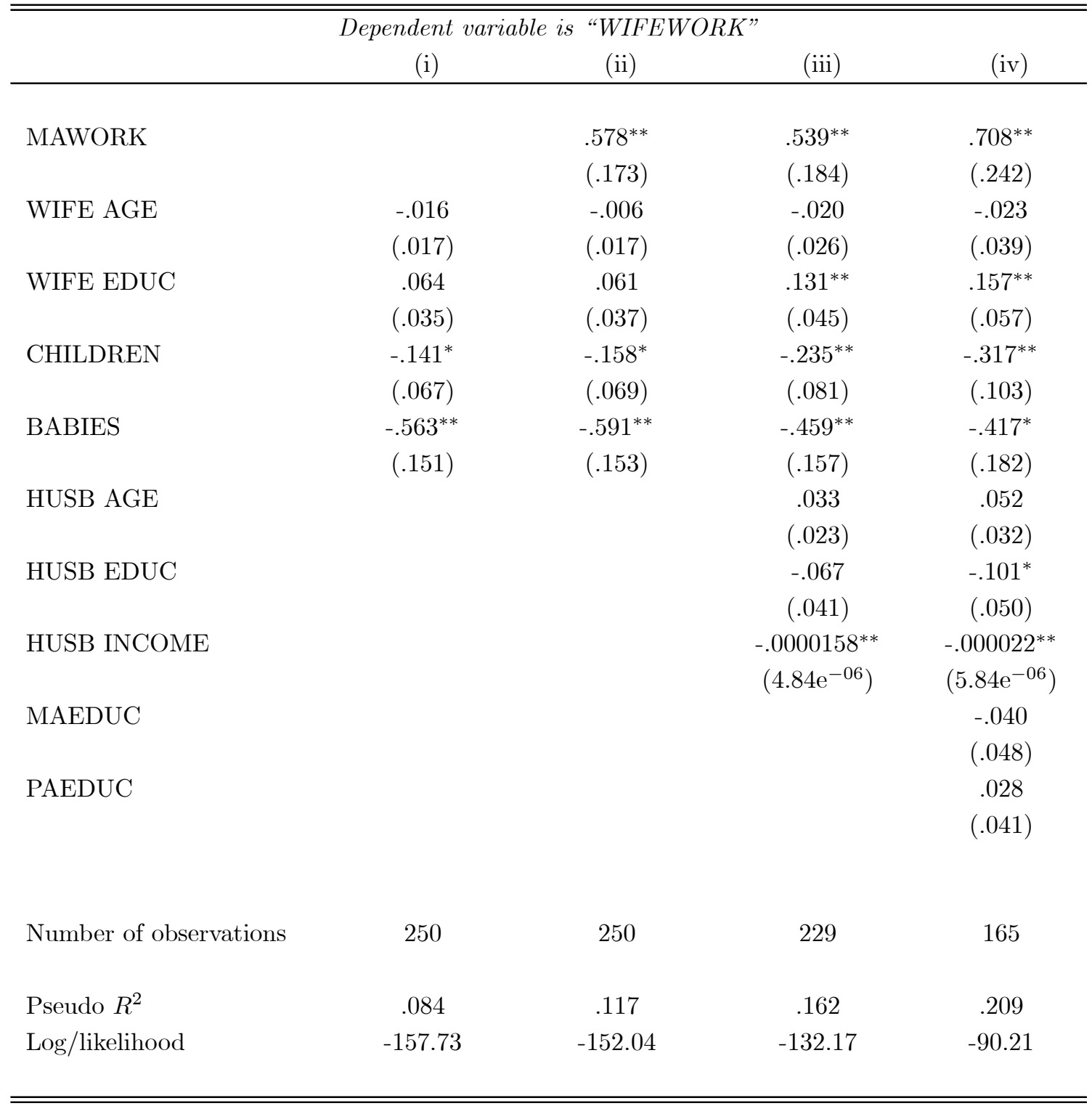

Notes: Robust standard errors are in parentheses. All regressions include a constant term and year effect. Model (iv) also includes husband's religion dummies and dummies for husband's self-assesment of family income at age 16 .

*Significance at $5 \%$ level. **Significance at $1 \%$ level. 
TABLe 3.7 Probit WHETHER WIFE WORKS ON MOTHER WORKING BEHAVIOR

\begin{tabular}{|c|c|c|c|}
\hline & \multicolumn{3}{|c|}{ Dependent variable is "WIFEWORK" } \\
\hline & Probit Coefficient & Robust St. Error & Marginal Effects \\
\hline MAWORK & $.842^{* *}$ & .272 & .323 \\
\hline WIFE AGE & -.053 & .043 & -.021 \\
\hline WIFE EDUC & $.254^{* *}$ & .079 & .100 \\
\hline CHILDREN & $-.255^{*}$ & .117 & -.101 \\
\hline BABIES & $-.571^{* *}$ & .199 & -.225 \\
\hline HUSB AGE & .061 & .036 & .024 \\
\hline HUSB EDUC & $-.173^{* *}$ & .062 & -.068 \\
\hline HUSB INCOME & $-.0000198^{* *}$ & $7.03 \mathrm{e}^{-06}$ & $-7.80 \mathrm{e}^{-06}$ \\
\hline MAEDUC & -.027 & .061 & -.011 \\
\hline PAEDUC & .048 & .051 & .019 \\
\hline FARM & -.610 & .561 & -.239 \\
\hline SM CITY & -.729 & .434 & -.284 \\
\hline MED CITY & -.219 & .488 & -.087 \\
\hline SUBURBS & $-1.71^{* *}$ & .516 & -.559 \\
\hline LG CITY & $-1.14^{*}$ & .539 & -.412 \\
\hline NEW ENGLAND & .440 & .802 & .164 \\
\hline MID. ATLANTIC & -.342 & .685 & -.135 \\
\hline E.N. CENTRAL & -.459 & .667 & -.181 \\
\hline W.N. CENTRAL & -.675 & .741 & -.262 \\
\hline S. ATLANTIC & .616 & .799 & .226 \\
\hline W.S. CENTRAL & -1.34 & .708 & -.472 \\
\hline MOUNTAIN & -.213 & .712 & -.085 \\
\hline PACIFIC & .552 & .851 & .202 \\
\hline Number of observations & 159 & & \\
\hline Pseudo $R^{2}$ & .329 & & \\
\hline Log/likelihood & -73.43 & & \\
\hline
\end{tabular}

Notes: Robust standard errors are in parentheses. The regression includes a constant term and year effect. It also includes husband's religion dummies and dummies for husband's self-assesment of family income at age $16 . *$ Significance at $5 \%$ level. **Significance at $1 \%$ level. 
TABLE 3.8 EDUCATION LINEAR REGRESSION

\begin{tabular}{|c|c|c|c|c|c|c|}
\hline \multicolumn{7}{|c|}{ Dependent variable is wife's years of completed education } \\
\hline & (i) & (ii) & (iii) & (iv) & $(\mathrm{v})$ & (vi) \\
\hline HUSB INCOME & $\begin{array}{l}3.81 \mathrm{e}-06^{*} \\
(1.69 \mathrm{e}-06)\end{array}$ & $\begin{array}{l}3.34 \mathrm{e}-06^{*} \\
(1.67 \mathrm{e}-06)\end{array}$ & $\begin{array}{c}3.16 \mathrm{e}-06 \\
(1.69 \mathrm{e}-06)\end{array}$ & $\begin{array}{c}3.20 \mathrm{e}-06 \\
(1.67 \mathrm{e}-06)\end{array}$ & $\begin{array}{c}7.12 \mathrm{e}-06 \\
(4.03 \mathrm{e}-06)\end{array}$ & $\begin{array}{c}6.26 \mathrm{e}-06 \\
(4.09 \mathrm{e}-06)\end{array}$ \\
\hline HUSB INCOME2 & & & & & $\begin{array}{c}-3.28 \mathrm{e}-06 \\
(2.50 \mathrm{e}-011)\end{array}$ & $\begin{array}{c}-3.41 \mathrm{e}-06 \\
(2.54 \mathrm{e}-011)\end{array}$ \\
\hline HUSB BIRTHYR & $\begin{array}{l}.031^{* *} \\
(.007)\end{array}$ & $\begin{array}{l}.023^{* *} \\
(.007)\end{array}$ & $\begin{array}{l}.026^{* *} \\
(.007)\end{array}$ & $\begin{array}{l}.026^{* *} \\
(.007)\end{array}$ & $\begin{array}{r}-.0005 \\
(.028)\end{array}$ & $\begin{array}{c}.006 \\
.(028)\end{array}$ \\
\hline HUSB BIRTHYR2 & & & & & $\begin{array}{c}.0003 \\
(.0003)\end{array}$ & $\begin{array}{l}.0003 \\
(.0003)\end{array}$ \\
\hline HUSB AGE & $\begin{array}{c}.013 \\
(.008)\end{array}$ & $\begin{array}{c}.011 \\
(.008)\end{array}$ & $\begin{array}{c}.012 \\
(.008)\end{array}$ & $\begin{array}{c}.011 \\
(.008)\end{array}$ & $\begin{array}{l}-.008 \\
(.047)\end{array}$ & $\begin{array}{c}.002 \\
(.047)\end{array}$ \\
\hline HUSB AGE2 & & & & & $\begin{array}{c}.0002 \\
(.0005)\end{array}$ & $\begin{array}{c}.0001 \\
(.0005)\end{array}$ \\
\hline HUSB EDUC & $\begin{array}{l}.481^{* *} \\
(.017)\end{array}$ & $\begin{array}{l}.445^{* *} \\
(.017)\end{array}$ & $\begin{array}{l}.456^{* *} \\
(.018)\end{array}$ & $\begin{array}{l}.441^{* *} \\
(.018)\end{array}$ & $\begin{array}{l}.435^{* *} \\
(.019)\end{array}$ & $\begin{array}{l}.421^{* *} \\
(.019)\end{array}$ \\
\hline MAEDUC & & $\begin{array}{l}.093^{* *} \\
(.015)\end{array}$ & & $\begin{array}{l}.083^{* *} \\
(.017)\end{array}$ & $\begin{array}{l}.087^{* *} \\
(.018)\end{array}$ & $\begin{array}{l}.075^{* *} \\
(.016)\end{array}$ \\
\hline PAEDUC & & & $\begin{array}{l}.051^{* *} \\
(.012)\end{array}$ & $\begin{array}{c}.015 \\
(.013)\end{array}$ & $\begin{array}{c}.008 \\
(.014)\end{array}$ & $\begin{array}{c}.007 \\
(.014)\end{array}$ \\
\hline FARM & & & & & & $\begin{array}{c}.237 \\
(.145)\end{array}$ \\
\hline SM CITY & & & & & & $\begin{array}{c}.105 \\
(.130)\end{array}$ \\
\hline MED CITY & & & & & & $\begin{array}{c}.179 \\
(.159)\end{array}$ \\
\hline SUBURBS & & & & & & $\begin{array}{l}.346^{*} \\
(.166)\end{array}$ \\
\hline LG CITY & & & & & & $\begin{array}{c}.101 \\
(.162)\end{array}$ \\
\hline $\begin{array}{l}\text { Number } \\
\text { of observations }\end{array}$ & 2557 & 2557 & 2557 & 2557 & 2435 & 2365 \\
\hline$R^{2}$ & .4016 & 0.4128 & 0.4065 & 0.4131 & 0.4170 & 0.4057 \\
\hline
\end{tabular}

Notes: Robust standard errors are in parentheses. All regressions include a constant term. Model (v) also includes husband's religion dummies and dummies for husband's self-assesment of family income at age 16. Model (vi) adds the 9 regional dummies to Model (v). *Significance at $5 \%$ level. **Significance at $1 \%$ level. 
TABLE 3.9 EDUCATION ORDERED PROBIT REGRESSION

\begin{tabular}{|c|c|c|c|c|}
\hline & \multicolumn{4}{|c|}{ Dependent Variable is Education of wife } \\
\hline & (i) & (i) & (iii) & (iv) \\
\hline \multirow[t]{2}{*}{ HUSB INCOME } & $6.23 \mathrm{e}-06^{* *}$ & $5.72 \mathrm{e}-06^{* *}$ & $5.71 \mathrm{e}-06^{* *}$ & $5.51 \mathrm{e}-06^{* *}$ \\
\hline & $(1.05 \mathrm{e}-06)$ & $(1.06 \mathrm{e}-06)$ & $(1.06 \mathrm{e}-06)$ & $(1.07 \mathrm{e}-06)$ \\
\hline \multirow[t]{2}{*}{ HUSB BIRTHYR } & $.022^{* *}$ & $.018^{* *}$ & $.019^{* *}$ & $.017^{* *}$ \\
\hline & $(.004)$ & $(.004)$ & $(.004)$ & $(.004)$ \\
\hline \multirow[t]{2}{*}{ HUSB AGE } & $.011^{*}$ & $.009^{*}$ & $.010^{*}$ & $.009^{*}$ \\
\hline & $(.005)$ & $(.005)$ & $(.004)$ & $(.005)$ \\
\hline \multirow[t]{2}{*}{ HUSB HS } & $.792^{* *}$ & $.735^{* *}$ & $.764^{* *}$ & $.733^{* *}$ \\
\hline & $(.077)$ & $(.078)$ & $(.079)$ & $(.079)$ \\
\hline \multirow[t]{2}{*}{ HUSB COLL } & $1.74^{* *}$ & $1.60^{* *}$ & $1.63^{* *}$ & $1.57^{* *}$ \\
\hline & $(.085)$ & $(.088)$ & $(.088)$ & $(.089)$ \\
\hline \multirow[t]{2}{*}{ MAHS } & & $.299^{* *}$ & & $.262^{* *}$ \\
\hline & & $(.055)$ & & $(.059)$ \\
\hline \multirow[t]{2}{*}{ MACOLL } & & $.551^{* *}$ & & $.435^{* *}$ \\
\hline & & $(.079)$ & & $(.087)$ \\
\hline \multirow[t]{2}{*}{ PAHS } & & & $.139^{*}$ & .031 \\
\hline & & & $(.058)$ & $(.063)$ \\
\hline \multirow[t]{2}{*}{ PACOLL } & & & $.458^{* *}$ & $.287^{* *}$ \\
\hline & & & $(.073)$ & $(.081)$ \\
\hline Number of observations & 2557 & 2557 & 2557 & 2557 \\
\hline Pseudo $R^{2}$ & .1876 & 0.1988 & 0.1954 & 0.2016 \\
\hline Log/likelihood & -2071.31 & -2042.64 & -2051.24 & -2035.51 \\
\hline
\end{tabular}

Notes: Robust standard errors are in parentheses. All regressions include a constant term.

*Significance at $5 \%$ level. **Significance at $1 \%$ level. 
TABle 3.10 EdUCATION ORDERED PROBIT REgRESSION

\begin{tabular}{lcccc}
\hline \hline & \multicolumn{2}{c}{$\begin{array}{c}\text { Dependent } \text { Variable is } \text { Education of wife } \\
\text { Probit Estimate }\end{array}$} & Robust St. Error & \multicolumn{2}{c}{ Marginal Effects } \\
& & & Wife less HS & Wife some college \\
\hline & & & & \\
HUSB INCOME & $1.05 \mathrm{e}-05^{* *}$ & $2.61 \mathrm{e}-06$ & $-1.45 \mathrm{e}-06^{* *}$ & $4.05 \mathrm{e}-06^{* *}$ \\
HUSB INCOME2 & $-4.28 \mathrm{e}-11$ & $1.81 \mathrm{e}-11$ & $5.90 \mathrm{e}-12$ & $-1.65 \mathrm{e}-11$ \\
HUSB BIRTHYR & .010 & .017 & -.0014 & .0038 \\
HUSB BIRTHYR2 & .0001 & .0002 & $-1.7 \mathrm{e}-05$ & $4.75 \mathrm{e}-05$ \\
HUSB AGE & .024 & .028 & -.003 & .009 \\
HUSB AGE2 & -.0001 & .0003 & $1.54 \mathrm{e}-05$ & $-4.29 \mathrm{e}-05$ \\
HUSB HS & $.733^{* *}$ & .081 & $-.085^{* *}$ & $.284^{* *}$ \\
HUSB COLL & $1.53^{* *}$ & .093 & $-.248^{* *}$ & $.535^{* *}$ \\
MAHS & $.274^{* *}$ & .062 & $-.036^{* *}$ & $.106^{* *}$ \\
MACOLL & $.432^{* *}$ & .091 & $-.048^{* *}$ & $.170^{* *}$ \\
PAHS & .019 & .065 & -.0027 & .0075 \\
PACOLL & $.267^{* *}$ & .084 & $-.0327^{* *}$ & $.104^{* *}$ \\
PROTESTANT & .040 & .210 & -.0056 & .015 \\
CATHOLIC & .041 & .213 & -.0056 & .016 \\
JEWISH & $.773^{* *}$ & .282 & $-.062^{* *}$ & $.299^{* *}$ \\
ATHEIST & -.175 & .241 & .027 & -.065 \\
AVERAGE & $-5.91 \mathrm{e}-04$ & .058 & $8.15 \mathrm{e}-05$ & $-2.28 \mathrm{e}-04$ \\
ABOVE & .103 & .078 & -.0136 & .040 \\
Number of observations & 2435 & & & \\
Pseudo $R^{2}$ & & & & \\
Log/likelihood & -1919.87 & & & \\
& & & & \\
\hline \hline
\end{tabular}

Notes: Robust standard errors are in parentheses. The regression includes a constant term. The marginal effects are computed at the mean for our sample. *Significance at $5 \%$ level. **Significance at $1 \%$ level. 
TABle 3.11 Education ordered Probit marginal EFFECts: Cohort I to III

\begin{tabular}{lcccccc}
\hline \hline & \multicolumn{3}{c}{ Wife less than High School } & \multicolumn{3}{c}{ Wife Some College } \\
& Cohort I & Cohort II & Cohort III & Cohort I & Cohort II & Cohort III \\
\hline HUSB INCOME & $-2.11 \mathrm{e}-06^{*}$ & $-5.95 \mathrm{e}-07$ & $-1.03 \mathrm{e}-06^{*}$ & $2.88 \mathrm{e}-06^{*}$ & $1.71 \mathrm{e}-06$ & $6.25 \mathrm{e}-06^{*}$ \\
HUSB INCOME2 & $9.18 \mathrm{e}-12$ & $-1.48 \mathrm{e}-12$ & $4.93 \mathrm{e}-12$ & $-1.25 \mathrm{e}-11$ & $4.27 \mathrm{e}-12$ & $-2.99 \mathrm{e}-11$ \\
HUSB BIRTHYR & $-.067^{*}$ & .028 & .007 & $.091^{*}$ & -.082 & -.041 \\
HUSB BIRTHYR2 & $.0014^{*}$ & -.0004 & $-6.93 \mathrm{e}-05$ & $-.0019^{*}$ & .0013 & .0004 \\
HUSB AGE & .0032 & -.008 & -.0016 & -.0044 & .023 & .0097 \\
HUSB AGE2 & $-5.59 \mathrm{e}-05$ & $6.64 \mathrm{e}-05$ & $1.28 \mathrm{e}-05$ & $7.63 \mathrm{e}-05$ & -.0002 & $-7.77 \mathrm{e}-05$ \\
HUSB HS & $-.131^{* *}$ & $-.103^{* *}$ & $-.036^{* *}$ & $.213^{* *}$ & $.364^{* *}$ & $.261^{* *}$ \\
HUSB COLL & $-.260^{* *}$ & $-.298^{* *}$ & $-.173^{* *}$ & $.431^{* *}$ & $.619^{* *}$ & $.560^{* *}$ \\
MAHS & $-.063^{*}$ & $-.036^{* *}$ & $-.017^{*}$ & $.100^{*}$ & $.108^{* *}$ & $.100^{*}$ \\
MACOLL & $-.074^{*}$ & $-.044^{* *}$ & $-.021^{* *}$ & $.133^{*}$ & $.162^{* *}$ & $.154^{* *}$ \\
PAHS & -.018 & .019 & -.005 & .026 & -.030 & .030 \\
PACOLL & -.027 & -.017 & $-.021^{* *}$ & .040 & .053 & $.143^{* *}$ \\
PROTESTANT & -.135 & -.003 & .033 & .156 & .009 & -.210 \\
CATHOLIC & -.111 & .0014 & .036 & .193 & -.004 & -.184 \\
JEWISH & $-.129^{* *}$ & -.051 & $-.043^{* *}$ & $.368^{* *}$ & .238 & $.472^{* *}$ \\
ATHEIST & -.017 & .070 & .042 & .024 & -.142 & -.178 \\
AVERAGE & -.023 & .010 & -.002 & .032 & -.029 & .011 \\
ABOVE & .022 & -.011 & -.011 & -.028 & .035 & .072 \\
Number of & & & & & & 856 \\
observations & 549 & 942 & 856 & 549 & 942 & \\
\hline \hline
\end{tabular}

Notes: Birth Cohort I: [1915-1930). Birth Cohort II: [1930 - 1945). Birth Cohort III: [1945 - 1960).

The marginal effects are computed at the mean for our sample. *Significance at $5 \%$ level. **Significance at $1 \%$ level. 


\section{Appendix A1. Variables Name and Definition}

\begin{tabular}{|c|c|}
\hline Variable Name & Variable definition \\
\hline WIFEWORK & $\begin{array}{l}\text { Wifework }=1 \text { if wife employed full time, or temporary away from } \\
\text { job because of illness, vacation or strike during the week } \\
\text { preceding the interview }\end{array}$ \\
\hline MAWORK & $\begin{array}{l}\text { Mawork=1 if husband's mother ever worked for pay for as long } \\
\text { as } 1 \text { year after he was born and before he was } 14\end{array}$ \\
\hline WIFE AGE & Wife's age \\
\hline WIFE EDUC & Wife's years of completed education \\
\hline CHILDREN & Number of children the husband has ever had \\
\hline BABIES & Number of children less than 6 in the household \\
\hline HUSB INCOME & $\begin{array}{l}\text { Husband's labor earnings in constant dollars (base=1986). } \\
\text { Calculated as midpoint of categorical variable }\end{array}$ \\
\hline HUSB BIRTHYR & Husband's year of birth \\
\hline HUSB AGE & Husband's age \\
\hline HUSB EDUC & Husband's years of completed education \\
\hline MAEDUC & Husband's mother years of completed education \\
\hline PAEDUC & Husband's father years of completed education \\
\hline WIFE HS & WIFE HS $=1$ if Wife has a High School diploma \\
\hline WIFE COLL & WIFE COLL $=1$ if Wife has at least some years of College \\
\hline HUSB HS & HUSB HS $=1$ if Husband has a High School diploma \\
\hline HUSB COLL & HUSB COLL $=1$ if Husband has at least some years of College \\
\hline
\end{tabular}




\begin{tabular}{|c|c|}
\hline Variable Name & Variable Definition \\
\hline MAHS & MAHS $=1$ if Husband's mother has a High School diploma \\
\hline MACOLL & $\begin{array}{l}\text { MACOLL }=1 \text { if Husband's mother has at least some years of } \\
\text { College }\end{array}$ \\
\hline PAHS & PAHS $=1$ if Husband's father has High School diploma \\
\hline PACOLL & $\begin{array}{l}\text { PACOLL }=1 \text { if Husband's father has at least some years of } \\
\text { College }\end{array}$ \\
\hline PROTESTANT & PROTESTANT $=1$ if husband was raised as protestant \\
\hline CATHOLIC & CATHOLIC $=1$ if husband was raised as catholic \\
\hline JEWISH & $\mathrm{JEWISH}=1$ if husband was raised as jewish \\
\hline ATHEIST & ATHEIST $=1$ if husband was raised in no religion \\
\hline OTHER & $\begin{array}{l}\text { OTHER }=1 \text { if husband was raised in other religion and/or church } \\
\text { and denomination (i.e. Moslem/Islam, Christian, Buddhism etc.) }\end{array}$ \\
\hline BELOW & $\begin{array}{l}\text { BELOW }=1 \text { if husband deems his family income at age } 16 \text { to be } \\
\text { below average compared with American families at the time }\end{array}$ \\
\hline AVERAGE & $\begin{array}{l}\text { AVERAGE }=1 \text { if husband deems his family income at age } 16 \text { to } \\
\text { be at average compared with American families at the time }\end{array}$ \\
\hline ABOVE & $\begin{array}{l}\mathrm{ABOVE}=1 \text { if husband deems his family income at age } 16 \text { to be } \\
\text { above average compared with American families at the time }\end{array}$ \\
\hline COUNTRY & $\begin{array}{l}\text { COUNTRY }=1 \text { if husband lived in open country but not on a } \\
\text { farm at age } 16\end{array}$ \\
\hline FARM & $\mathrm{FARM}=1$ if husband lived in a farm at age 16 \\
\hline SM CITY & $\begin{array}{l}\text { SM CITY }=1 \text { if husband lived in small city or town } \\
\text { (under } 50,000 \text { ) at age } 16\end{array}$ \\
\hline
\end{tabular}




\begin{tabular}{|c|c|}
\hline Variable Name & Variable Definition \\
\hline MED CITY & $\begin{array}{l}\text { MED CITY }=1 \text { if husband lived in medium-size city } \\
(50,000-250,00) \text { at age } 16\end{array}$ \\
\hline SUBURBS & $\begin{array}{l}\text { SUBURBS }=1 \text { if husband lived in a suburb near a large city } \\
\text { at age } 16\end{array}$ \\
\hline LG CITY & $\begin{array}{l}\text { LG CITY=1 if husband lived in a large city (over 250,000) } \\
\text { at age } 16\end{array}$ \\
\hline NEW ENGLAND & $\begin{array}{l}\text { NEW ENGLAND }=1 \text { if husband lived in New England at age } \\
\text { 16. Includes: ME, VT, NH, MA, CT, RI }\end{array}$ \\
\hline MID ATLANTIC & $\begin{array}{l}\text { MID ATLANTIC }=1 \text { if husband lived in the Mid Atlantic } \\
\text { region at age } 16 . \text { Includes: NY, NJ, PA }\end{array}$ \\
\hline E.N. CENTRAL & $\begin{array}{l}\text { E.N. CENTRAL }=1 \text { if husband lived in the East North Central } \\
\text { region at age } 16 \text {. Includes: WI, IL, IN, MI, OH }\end{array}$ \\
\hline W.N. CENTRAL & $\begin{array}{l}\text { W.N. CENTRAL }=1 \text { if husband lived in the West North Central } \\
\text { region at age } 16 \text {. Includes: MN, IA, MO, ND, SD, NE, KS }\end{array}$ \\
\hline S. ATLANTIC & $\begin{array}{l}\text { S. ATLANTIC }=1 \text { if husband lived in the South Atlantic region } \\
\text { at age } 16 . \text { Includes: DE, MD, WV, VA, NC, SC, GA, FL, DC }\end{array}$ \\
\hline E.S. CENTRAL & $\begin{array}{l}\text { E.S. CENTRAL }=1 \text { if husband lived in the East South Central } \\
\text { region at age } 16 . \text { Includes: KY, TN, AL, MS }\end{array}$ \\
\hline W.S. CENTRAL & $\begin{array}{l}\text { W.S. CENTRAL }=1 \text { if husband lived in the West South Central } \\
\text { region at age } 16 \text {. Includes: AR, OK, LA, TX }\end{array}$ \\
\hline MOUNTAIN & $\begin{array}{l}\text { MOUNTAIN }=1 \text { if husband lived in the region that includes MT, } \\
\text { ID, WY, NV, UT, CO, AZ, and NM at age } 16\end{array}$ \\
\hline PACIFIC & $\begin{array}{l}\text { PACIFIC }=1 \text { if husband lived in the Pacific region at age } 16 . \\
\text { Includes: WA, OR, CA, AK, HI }\end{array}$ \\
\hline
\end{tabular}




\section{Appendix A2. Summary Characteristics by Cohort}

\begin{tabular}{|c|c|c|c|c|c|c|c|}
\hline \multirow[t]{2}{*}{ Variable } & \multicolumn{3}{|c|}{$\begin{array}{c}\text { Sample Means } \\
\text { (Std. Dev.) }\end{array}$} & \multirow[t]{2}{*}{ Variables } & \multicolumn{3}{|c|}{ Sample Means } \\
\hline & [1915-1930) & [1930-1945) & [1945-1960) & & [1915-1930) & [1930-1945) & [1945-1960) \\
\hline \multirow[t]{2}{*}{ HUSB INCOME } & 37192.65 & 37951.01 & 33227.43 & PROTESTANT & .670 & .669 & .623 \\
\hline & $(31688.32)$ & $(24340)$ & $(22684.22)$ & CATHOLIC & .253 & .271 & .317 \\
\hline \multirow[t]{2}{*}{ HUSB AGE } & 57.64 & 45.78 & 37.69 & JEWISH & .041 & .024 & .024 \\
\hline & $(5.49)$ & $(6.62)$ & $(4.74)$ & ATHEIST & .020 & .029 & .031 \\
\hline \multirow[t]{2}{*}{ HUSB BIRTHYR } & 1923.41 & 1937.83 & 1950.38 & BELOW & .361 & .275 & .225 \\
\hline & $(3.98)$ & $(4.22)$ & $(3.93)$ & AVERAGE & .478 & .536 & .555 \\
\hline \multirow[t]{2}{*}{ HUSB EDUC } & 12.67 & 13.62 & 14.32 & ABOVE & .160 & .189 & .220 \\
\hline & $(3.31)$ & $(3.08)$ & $(2.73)$ & COUNTRY & .080 & .121 & .126 \\
\hline \multirow[t]{2}{*}{ WIFE AGE } & 52.79 & 42.23 & 35.92 & FARM & .290 & .225 & .119 \\
\hline & $(6.90)$ & $(7.02)$ & $(4.61)$ & SM CITY & .335 & .329 & .341 \\
\hline \multirow[t]{2}{*}{ WIFE EDUC } & 12.34 & 13.04 & 13.62 & MED CITY & .134 & .113 & .146 \\
\hline & $(2.29)$ & $(2.47)$ & $(2.42)$ & SUBURBS & .035 & .089 & .149 \\
\hline \multirow[t]{2}{*}{ MAEDUC } & 8.92 & 10.44 & 11.5 & LG CITY & .124 & .123 & .117 \\
\hline & $(3.58)$ & $(3.12)$ & $(2.86)$ & NEW ENGLAND & .073 & .05 & .064 \\
\hline \multirow[t]{2}{*}{ PAEDUC } & 8.05 & 9.63 & 11.33 & MID ATLANTIC & .195 & .164 & .196 \\
\hline & $(3.84)$ & $(3.94)$ & $(3.78)$ & E.N. CENTRAL & .247 & .231 & .231 \\
\hline HUSB HS & .341 & .331 & .283 & W.N. CENTRAL & .127 & .111 & .087 \\
\hline HUSB COLL & .387 & .521 & .649 & S.A. ATLANTIC & .138 & .153 & .126 \\
\hline WIFE HS & .531 & .448 & .386 & E.S. CENTRAL & .067 & .073 & .052 \\
\hline WIFE COLL & .279 & .415 & .529 & W.S. CENTRAL & .058 & .085 & .078 \\
\hline MAHS & .233 & .381 & .520 & MOUNTAIN & .050 & .045 & .059 \\
\hline MACOLL & .100 & .143 & .196 & PACIFIC & .045 & .088 & .105 \\
\hline PAHS & .149 & .233 & .328 & & & & \\
\hline PACOLL & .086 & .164 & .282 & & & & \\
\hline No. observations & 537 & 920 & 826 & & 537 & 920 & 826 \\
\hline
\end{tabular}

